\title{
Biogeochemical data from terrestrial and aquatic ecosystems in a periglacial catchment, West Greenland
}

\author{
Tobias Lindborg $^{1,2}$, Johan Rydberg ${ }^{3}$, Mats Tröjbom ${ }^{4}$, Sten Berglund ${ }^{5}$, Emma Johansson ${ }^{1,6}$, \\ Anders Löfgren $^{7}$, Peter Saetre ${ }^{1}$, Sara Nordén ${ }^{1}$, Gustav Sohlenius ${ }^{8}$, Eva Andersson ${ }^{1}$, Johannes Petrone ${ }^{1}$, \\ Micke Borgiel $^{9}$, Ulrik Kautsky ${ }^{1}$, and Hjalmar Laudon ${ }^{2}$ \\ ${ }^{1}$ Swedish Nuclear Fuel and Waste Management Co. (SKB), P.O. Box 250, 10124 Stockholm, Sweden \\ ${ }^{2}$ Department of Forest Ecology and Management, Swedish University of Agricultural Sciences, \\ 90183 Umeå, Sweden \\ ${ }^{3}$ Department of Ecology and Environmental Science, Umeå University, 90187 Umeå, Sweden \\ ${ }^{4}$ Mats Tröjbom Konsult AB, Slänningevägen 28, 76172 Norrtälje, Sweden \\ ${ }^{5}$ HydroResearch AB, Stora Marknadsvägen 15, 18334 Täby, Sweden \\ ${ }^{6}$ Department of Physical Geography, Bert Bolin Centre for Climate Research, Stockholm University, \\ 10691 Stockholm, Sweden \\ ${ }^{7}$ EcoAnalytica, Slalomvägen 28, 12949 Hägersten, Sweden \\ ${ }^{8}$ Geological Survey of Sweden (SGU), P.O. Box 670, 75128 Uppsala, Sweden \\ ${ }^{9}$ Sveriges Vattenekologer AB, Marsjö Hvilan, 64394 Vingåker, Sweden \\ Correspondence to: Tobias Lindborg (tobias.lindborg@skb.se)
}

Received: 1 June 2016 - Published in Earth Syst. Sci. Data Discuss.: 15 June 2016

Revised: 27 August 2016 - Accepted: 12 September 2016 - Published: 23 September 2016

\begin{abstract}
Global warming is expected to be most pronounced in the Arctic where permafrost thaw and release of old carbon may provide an important feedback mechanism to the climate system. To better understand and predict climate effects and feedbacks on the cycling of elements within and between ecosystems in northern latitude landscapes, a thorough understanding of the processes related to transport and cycling of elements is required. A fundamental requirement to reach a better process understanding is to have access to high-quality empirical data on chemical concentrations and biotic properties for a wide range of ecosystem domains and functional units (abiotic and biotic pools). The aim of this study is therefore to make one of the most extensive field data sets from a periglacial catchment readily available that can be used both to describe present-day periglacial processes and to improve predictions of the future. Here we present the sampling and analytical methods, field and laboratory equipment and the resulting biogeochemical data from a state-of-the-art whole-ecosystem investigation of the terrestrial and aquatic parts of a lake catchment in the Kangerlussuaq region, West Greenland. This data set allows for the calculation of whole-ecosystem mass balance budgets for a long list of elements, including carbon, nutrients and major and trace metals. The data set is freely available and can be downloaded from PANGAEA: doi:10.1594/PANGAEA.860961.
\end{abstract}




\section{Introduction}

Arctic environments, including permafrost-dominated periglacial landscapes, play a fundamental role in the ongoing global climate change (Smol, 2012; Schuur et al., 2015). Currently immobile pools of organic matter in currently frozen soils are expected to be mobilised due to permafrost thaw potentially resulting in dramatic changes in the rate of release of carbon, nutrients and metals (McGuire et al., 2009; Schuur et al., 2015). Therefore, a thorough understanding of the processes related to the transport and cycling of elements within and between terrestrial and aquatic ecosystems is key to describing and quantifying the effects of climate change. This understanding is also vital for our ability to facilitate reliable forecasts regarding future changes in biogeochemical cycling.

In order to describe the ongoing effects of climate related impacts on Arctic landscapes and to predict the future, it is essential to have access to data regarding chemical concentrations and biotic properties for a wide range of ecosystem domains and functional units (abiotic and biotic pools). There are several studies investigating different aspects of Arctic ecosystems, in West Greenland (e.g., Anderson et al., 2008; Ryves et al., 2009; Sobek et al., 2014; Jessen et al., 2014; Whiteford et al., 2016) and elsewhere (e.g., Chapin et al., 1995: Rysgaard and Glud, 2007; Smol and Douglas, 2007; Tarnocai et al., 2009; Rydberg et al., 2010; Palmtag et al., 2015; Hindshaw et al., 2016: Lundin et al., 2016). These studies provided crucial insights of high-latitude ecosystems that have increased our understanding of the significance and sensitivity of periglacial landscapes. However, no or very few studies have taken a whole-ecosystem approach and looked simultaneously at both the terrestrial and the aquatic ecosystems of the Arctic landscape. Hence, there is a need for studies that take such a holistic approach in order to better understand how biogeochemical processes are connected (Solomon et al., 2015).

In this work, we present biogeochemical data from a detailed whole-ecosystem investigation of the terrestrial and aquatic parts of a lake catchment in the Kangerlussuaq region, West Greenland. The lake is situated close to the Greenland ice sheet and is hereinafter referred to as "Two Boat Lake", or, for brevity, TBL; the lake is also known as SS903 (e.g., Saros et al., 2014; Sobek et al., 2014; Whiteford et al., 2016) or as Lake 26/L26 and "Talik Lake" (e.g., Anderson et al., 2001; Harper et al., 2011). The field investigation reported in this work was performed within the Greenland Analogue Surface Project (GRASP) and was conducted between 2010 and 2015. The overarching objective of the GRASP project was to describe the hydrology and ecosystem functions under periglacial conditions on a landscape scale. Further, GRASP aims at constraining the impact of climate change on such systems over long timescales, including one to several glacial cycles.
The specific aim of the field data collection and methodology presented here was to provide biogeochemical data that - together with hydrological data and carbon age determinations - can be used in mass balance models of various elements for a periglacial catchment. The data will also inform process understanding on element transport within and between catchment ecosystems. The specific objectives of the present work are to describe the study design, sample collection and analytical methods and to make the biogeochemical data from the TBL catchment collected within the GRASP project available to the scientific community.

This paper is structured as follows. First, we provide a short site description that outlines the main site-specific conditions and defines the site in a regional context. This is followed by a section containing a presentation of the general study design and the conceptualisation of the investigated landscape system, followed by a detailed description of all installations, sample collection and in situ measurements for each of the studied ecosystem units. The next section describes all analytical methods used in the chemical analyses, as well as the methods used for data processing. Finally, the results section briefly describes and exemplifies the data made available in the PANGAEA database (doi:10.1594/PANGAEA.860961).

\section{Site description}

The TBL catchment, described in more detail by Johansson et al. $(2015 \mathrm{a}, \mathrm{b})$, is situated in close proximity to the Greenland ice sheet and approximately $30 \mathrm{~km}$ from the settlement of Kangerlussuaq, West Greenland (lat 67.125940, long -50.180370 ; Fig. 1). The catchment area is $1.56 \mathrm{~km}^{2}$, of which the lake occupies $0.37 \mathrm{~km}^{2}$. Although close to the ice margin, it is not part of the meltwater-driven surface water system (Fig. 2), and surface water runoff to the lake is generated by precipitation only. A digital elevation model (DEM) describing both the topography of the terrestrial part of the catchment and the bathymetry of the lake has been developed by Petrone et al. (2016; PANGAEA, doi:10.1594/PANGAEA.845258).

The Kangerlussuaq region is characterised by a hilly tundra landscape with numerous lakes and is the most extensive ice-free part of Greenland. Continuous permafrost, except where interrupted by through taliks under larger lakes, covers the area. An active layer of $0.15-5 \mathrm{~m}$, depending on soil type and vegetation cover, overlies the permafrost in the area from the settlement of Kangerlussuaq up to the ice sheet margin (van Tatenhove and Olesen, 1994). Measurements in the TBL catchment indicate an active layer depth around 0.4$2.0 \mathrm{~m}$ (Petrone et al., 2016). Permafrost depths in the range $300-400 \mathrm{~m}$ have been observed from temperature measurements in deep bedrock boreholes 5-6 km from TBL (Harper et al., 2011). 


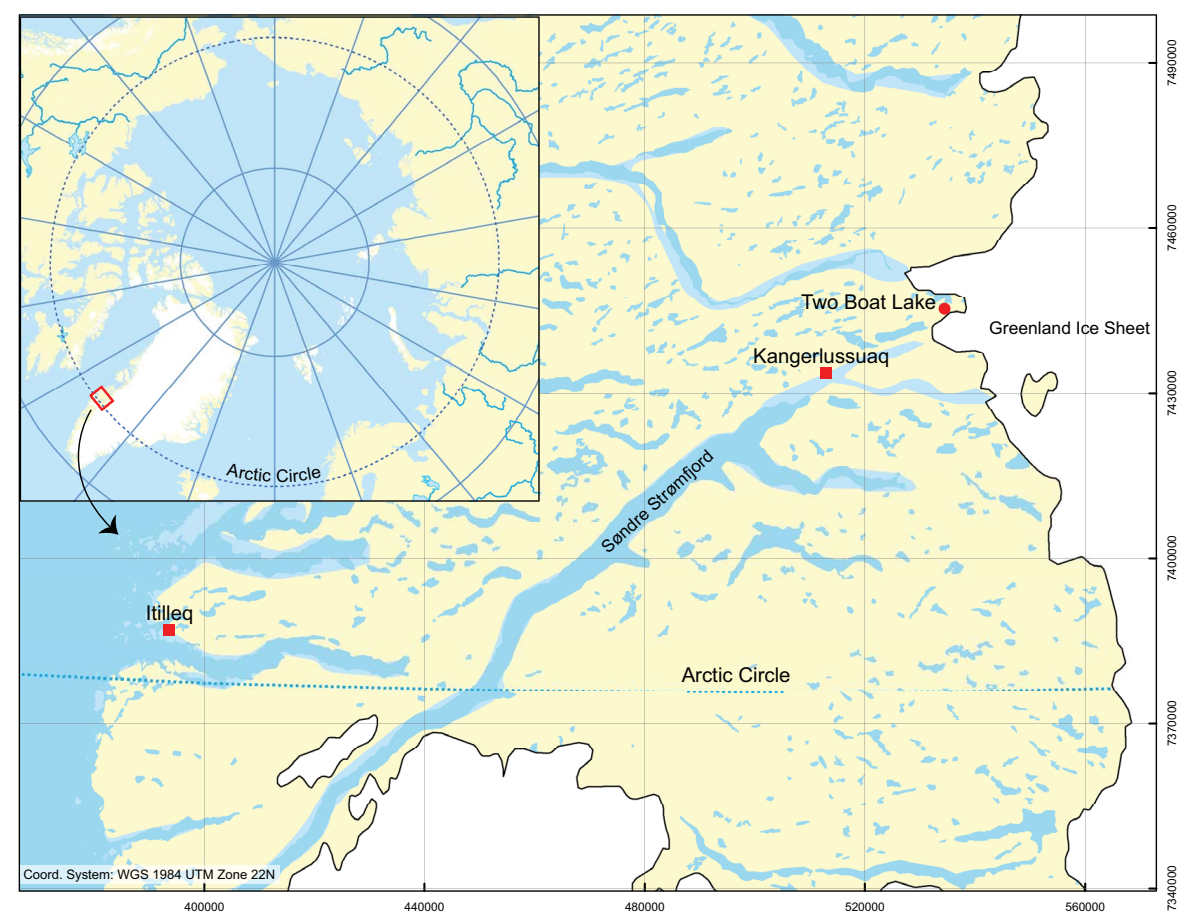

Figure 1. Map of West Greenland and location of Two Boat Lake catchment area. Modified from Johansson et al. (2015a).

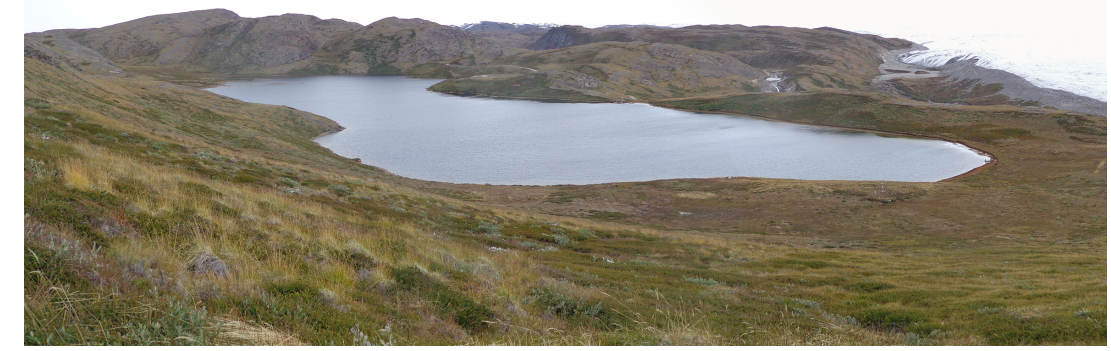

Figure 2. Photo of the Two Boat Lake catchment heading north east. To the right the Greenland ice sheet is seen.

The regional climate is dominated by relatively stable high-pressure cells over the ice sheet and can be characterised as continental (Engels and Helmens, 2010). The mean annual air temperature (MAAT) in Kangerlussuaq is $-5.1^{\circ} \mathrm{C}$ (measured 1977-2015; Cappelen, 2016). The MAAT observed for the available data period 2011-2015 in the TBL catchment is $-4.4^{\circ} \mathrm{C}$ while the MAAT in Kangerlussuaq for the corresponding period is $-5.3{ }^{\circ} \mathrm{C}$, indicating somewhat warmer temperatures in the TBL area. The regional climate is dry with a mean annual precipitation (corrected for wind and adhesion losses) of $173 \mathrm{~mm}$ in Kangerlussuaq, with $67 \mathrm{~mm}$ falling as snow and $106 \mathrm{~mm}$ as rain (Johansson et al., 2015a).

The hydrology of the TBL catchment has been extensively studied during the period 2010-2015. The meteorological and hydrological data collected by GRASP at TBL are presented in Johansson et al. (2015a;
doi:10.1594/PANGAEA.836178). Johansson et al. (2015b) developed a detailed water balance model of the TBL catchment. From a decadal perspective precipitation barely exceeds evapotranspiration, and the net annual water budget is alternating between positive and negative. According to these modelling results, the lake has had a surface water outflow in 1 out of 3 years during the last 30 years. Thus, TBL has no continuous surface outflow, and it may take several years between outflow events. Surface outflow from the lake was last observed during the summer of 2009 (Johansson et al., 2015b). There are no permanent streams in the catchment, which means that ice wedges provide the major transport routes of water from the catchment to the lake. The snow melt period (May-June) accounts for almost half of the inflow of water to the lake. 


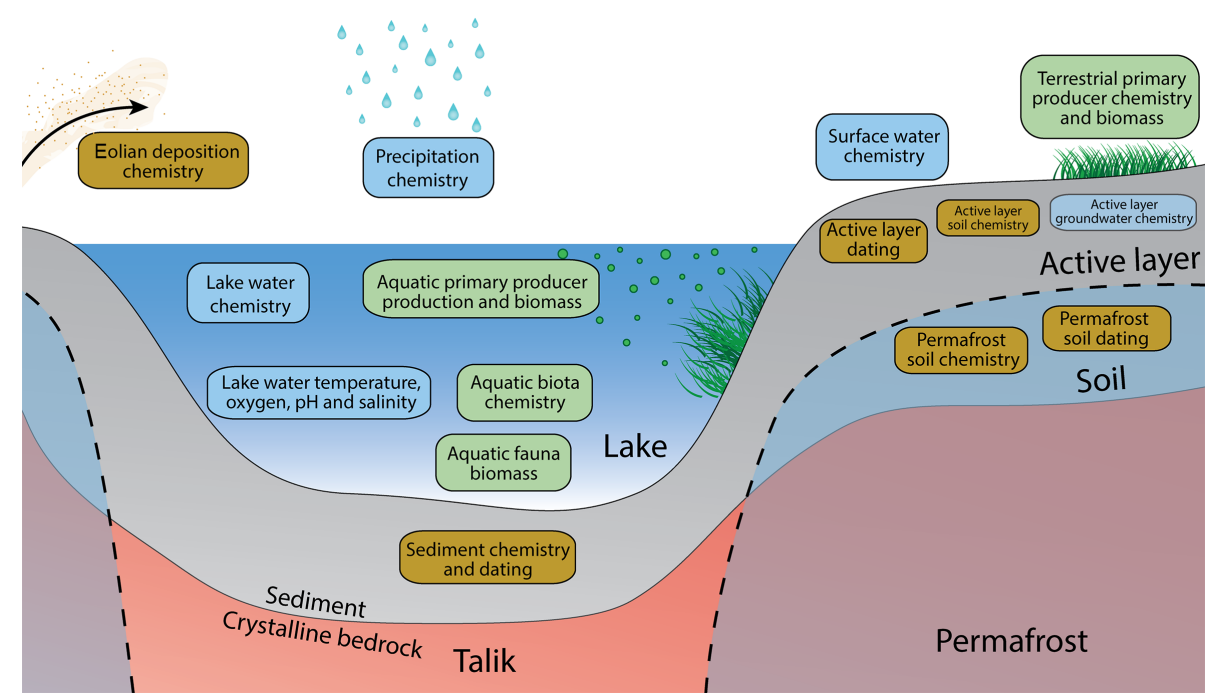

Figure 3. Conceptual model of the TBL catchment describing major ecosystem entities (boxes) in the landscape. Boxes are divided into water (blue), biotic (green) and solid matter (brown).

Maximum and average water depths in the lake are 29.9 and $11.3 \mathrm{~m}$, respectively, and lake volume is $4.29 \mathrm{Mm}^{3}$. Secchi depth is about $15 \mathrm{~m}$, indicating a photic depth of around $30 \mathrm{~m}$. A thick mat of Chara sp. and Bryophytes dominates the lake bottom down to $14 \mathrm{~m}$ depth. From a lake water chemistry and morphometry perspective, TBL is typical for precipitation-driven lakes close to the ice margin in the Kangerlussuaq area (Ryves et al., 2002; Clarhäll, 2011; Andersson et al., 2009; Sobek et al., 2014).

A model describing the spatial distribution of soil depth and active layer thickness was developed by Petrone et al. (2016). Soils in the TBL catchment are dominated by till and glaciofluvial deposits, which to a large extent are overlain by a $0.3-0.4 \mathrm{~m}$ thick layer of eolian silt to fine sand (Rydberg et al., 2016; Petrone et al., 2016). With the exception of areas with exposed bedrock or till, most of the catchment has a sparse but continuous vegetation cover. Meadow, dry grass and dwarf-shrub communities dominate the vegetation. There are no trees, and shrubs rarely exceed heights of $0.5 \mathrm{~m}$. The vegetation has been classified based on field surveys and aerial photos, and a vegetation map is available (Clarhäll, 2011).

\section{Installations, sampling and in situ measurements}

The overall study design and data collection protocol for TBL were based on a conceptual model describing the different functional units of the ecosystem (Fig. 3). By collecting biogeochemical data for all identified ecosystem units in the conceptual model and then combining them with the existing hydrological model (Johansson et al., 2015b) and geometrical information (Petrone et al., 2016), the purpose was to make it possible to develop numerical models describing the fluxes and accumulation of various elements on a catchment scale.

No specific target element was chosen for this work, but rather the aim has been to provide understanding of the general fluxes of dissolved and particulate matter in the system. Therefore, we analysed concentrations of carbon, nitrogen and phosphorus - together with their associated species and isotopic composition - as well as total concentrations of a long list of major and trace elements, which together with the hydrological model can help us to understand the fluxes in the landscape. Through the age determinations of different soil and sediment layers, together with estimates of biomass and primary production in both the terrestrial and aquatic systems, we also wanted to make it possible to capture the accumulation of various elements in different landscape units.

\subsection{Water in terrestrial areas}

\subsubsection{Lysimeters}

In August 2011, soil lysimeters were installed in three transects, each with two or five locations (Fig. 4a). At each location, two to five lysimeters - installed at approximately every $10 \mathrm{~cm}$ starting from $10 \mathrm{~cm}$ below the soil surface - form a depth profile down to the permafrost at about 35 to $70 \mathrm{~cm}$ soil depth (Fig. 5a and b). Lysimeters were installed at the same sites as the time-domain reflectometer instruments that were used to measure soil water content in the hydrological studies performed by Johansson et al. (2015a, b). Two of the transects are located in the wetter areas with peaty silt (transect 2 and 3), while the third transect (transect 1) is located in a drier area with eolian silt and fine sand (Fig. 4c; see also Rydberg et al., 2016). The lysimeters (10 cm long, $2 \mathrm{~cm}$ in diameter, with an attached hose) were made of porous PTFE 


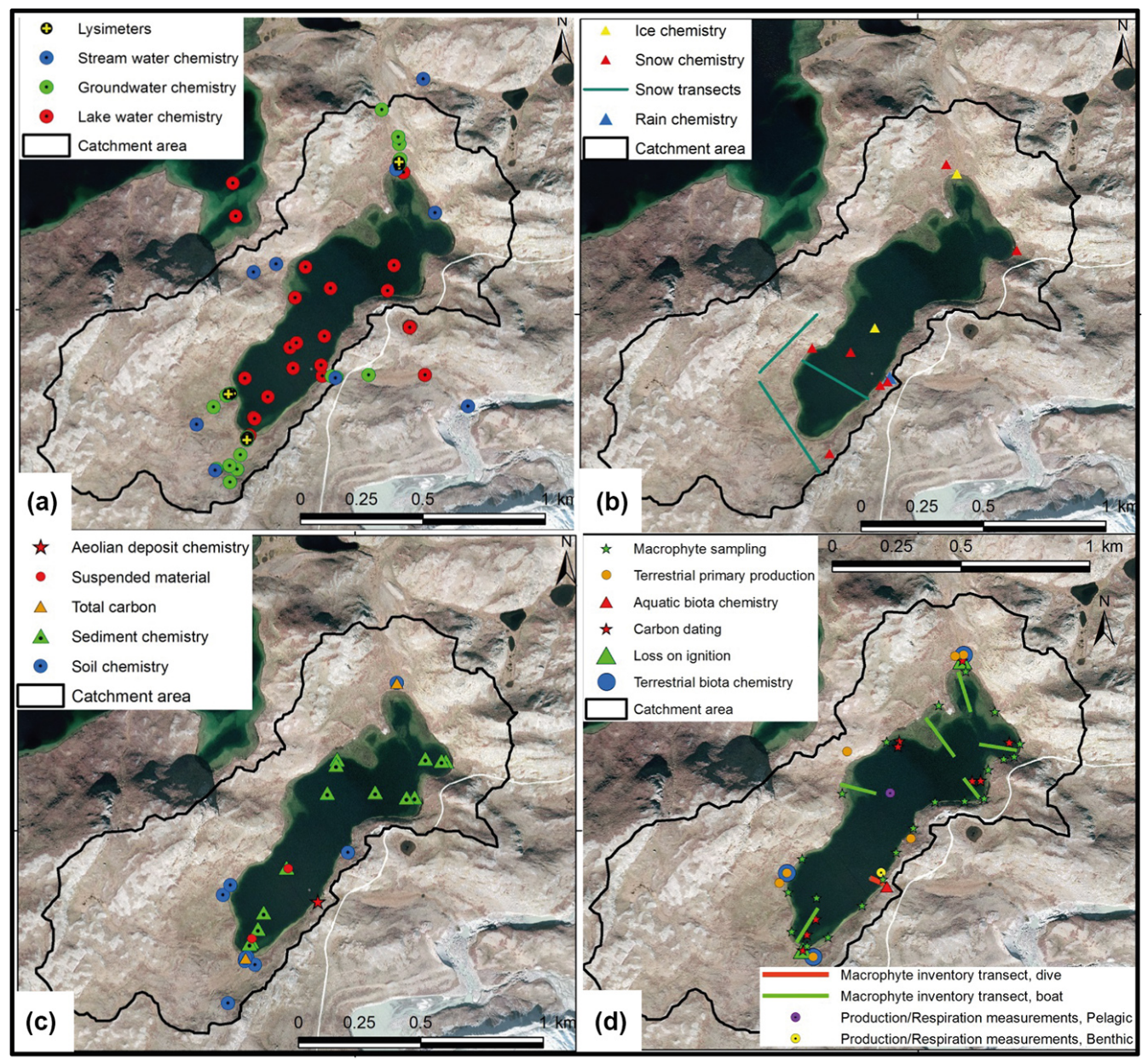

Figure 4. Maps illustrating sampling points, installations and measurement sites in the TBL catchment for groundwater and surface water (a), ice and precipitation (b), soils and sediment (c) and biota, carbon dating and soil loss on ignition (d). For information on coordinates and ID for each sampling location, see PANGAEA database (http://doi.pangaea.de/10.1594/PANGAEA.860961).

mixed with silica flour (pore size of $1 \mu \mathrm{m}$ ) similar to Petrone et al. (2007). Installation was done by digging a pit and inserting the lysimeters into the unaffected upslope wall of the pit to ensure a minimum impact on soil and hydrological conditions. The pit was then refilled in stratigraphic order.

In August or September each year from 2011 to 2014, water samples were collected from the lysimeters by attaching glass flasks (Fig. 5a) with vacuum to the plastic tube leading to the lysimeter. The flasks were then left for $12 \mathrm{~h}$ to extract water through suction from the lysimeters. No additional filtering was made, except for the filtering effect of the lysimeter itself. Samples were kept frozen awaiting analysis.

\subsubsection{Soil water wells and surface water}

In August or September from 2011 to 2014, soil water was collected from 15 soil water wells, which are described in detail in Johansson et al. (2015a; see also Fig. 4a). Water was sampled through a plastic tube attached to a pump, and was collected in plastic flasks. In addition, water in small temporary ponds and ice wedges was sampled by hand-filling plastic flasks (Fig. 4a). Both unfiltered and filtered $(0.45 \mu \mathrm{m})$ samples were collected. Samples were kept frozen awaiting analysis.

\subsection{Lake water}

\subsubsection{Water and ice sampling}

In April 2011-2014, June 2013-2014 and August/September from 2011 to 2014, lake water samples were collected using a Ruttner sampler (Figs. 4, 6). Both filtered $(0.45 \mu \mathrm{m})$ and unfiltered samples were collected in plastic flasks. In April 2011, 13 locations distributed across the lake were sampled at two depths $(5 \mathrm{~m}$ below the surface and $5 \mathrm{~m}$ above the sediment surface) in order to make a first evaluation of the spatial variations in the lake water chemistry (Fig. 4a). This evaluation showed very small differences between sites but considerable differences between the two sampled depths. In 


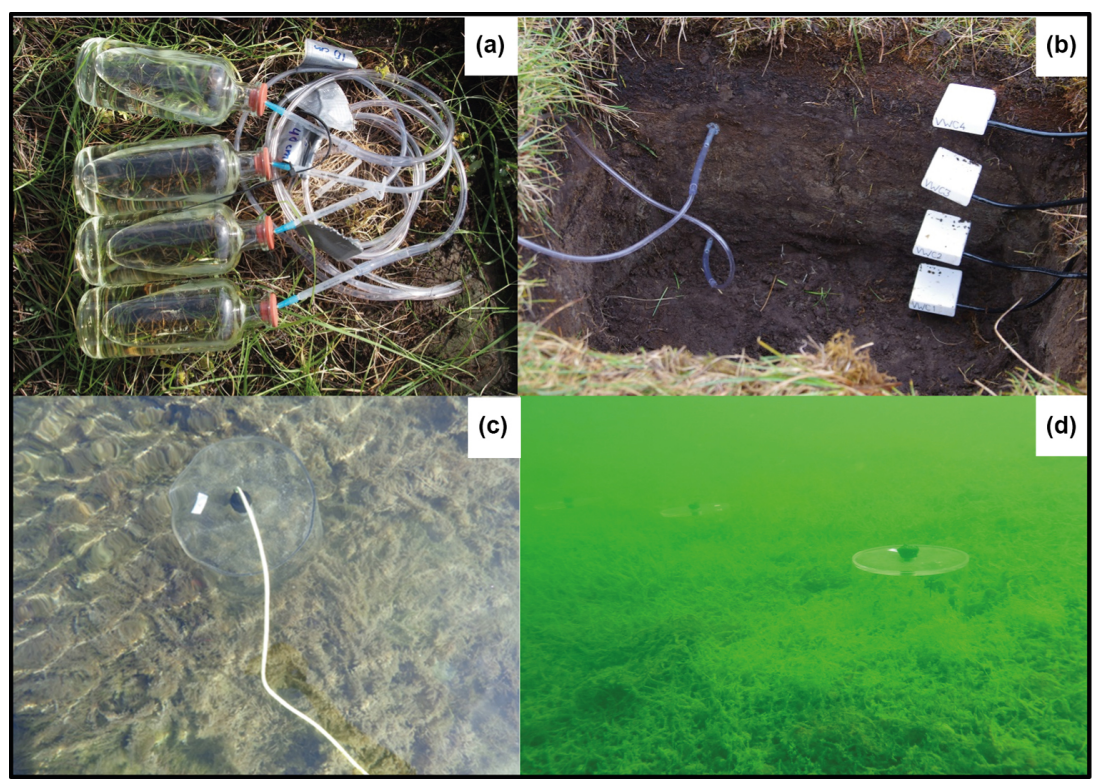

Figure 5. Photos of lysimeter flasks (a), lysimeter installation (left in the pit) (b) and respiration chambers for benthic production/respiration measurements (c, d).

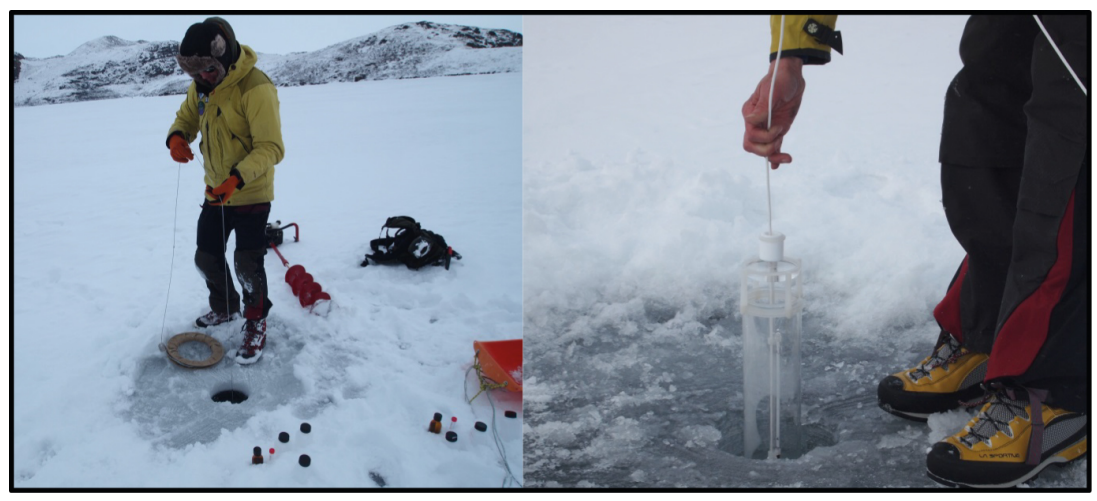

Figure 6. Lake water sampling on the lake ice using a Ruttner sampler.

light of this, subsequent lake water sampling was conducted at 5 and $25 \mathrm{~m}$ water depth at the centre of TBL (Fig. 4a). In August 2011 and August 2014, additional water samples were collected at temporary lake inlets and at the lake outlet (Fig. 4a). In winter (April) an ice auger was used to penetrate the ice (1.5-1.7 $\mathrm{m}$ thick, sampling points shown in Fig. 4b). During drilling, lake ice samples were collected in plastic bags, thawed and transferred to plastic flasks. Samples were kept frozen awaiting analysis.

\subsubsection{In situ measurements}

In April, June and September from 2012 to 2014, a TROLL 9500 multi-parameter probe was used for in situ measurements of $\mathrm{pH}$, temperature, dissolved oxygen and alkalinity profiles in the water column at the lake centre. The probe was lowered in steps with an average speed of about $1 \mathrm{~m}$ per minute, and a field computer (Panasonic Toughbook) was used for online monitoring to ensure that the probe had stabilised before lowering it further. The multi-parameter probe was maintained and calibrated regularly following the instruction in the TROLL 9500 operator's manual.

During the period from 15 June 2013 to 23 August 2014 (except for the period from 22 March 2014 to 26 June 2014), continuous measurements of oxygen saturation and temperature were conducted at two depths close to the lake outlet using HOBO U26-001 loggers. During the first part of the measurement period the loggers were placed at 5 and $17 \mathrm{~m}$ water depth, but when they were redeployed after maintenance on the 23 August 2013 the loggers were placed at 8 and $20 \mathrm{~m}$ water depth.

Additionally, water temperature was measured at approximately $4.3 \mathrm{~m}$ water depth by two Leveltroll 700 transducers (accuracy of $\pm 0.1 \%$ ) that were placed directly on the 


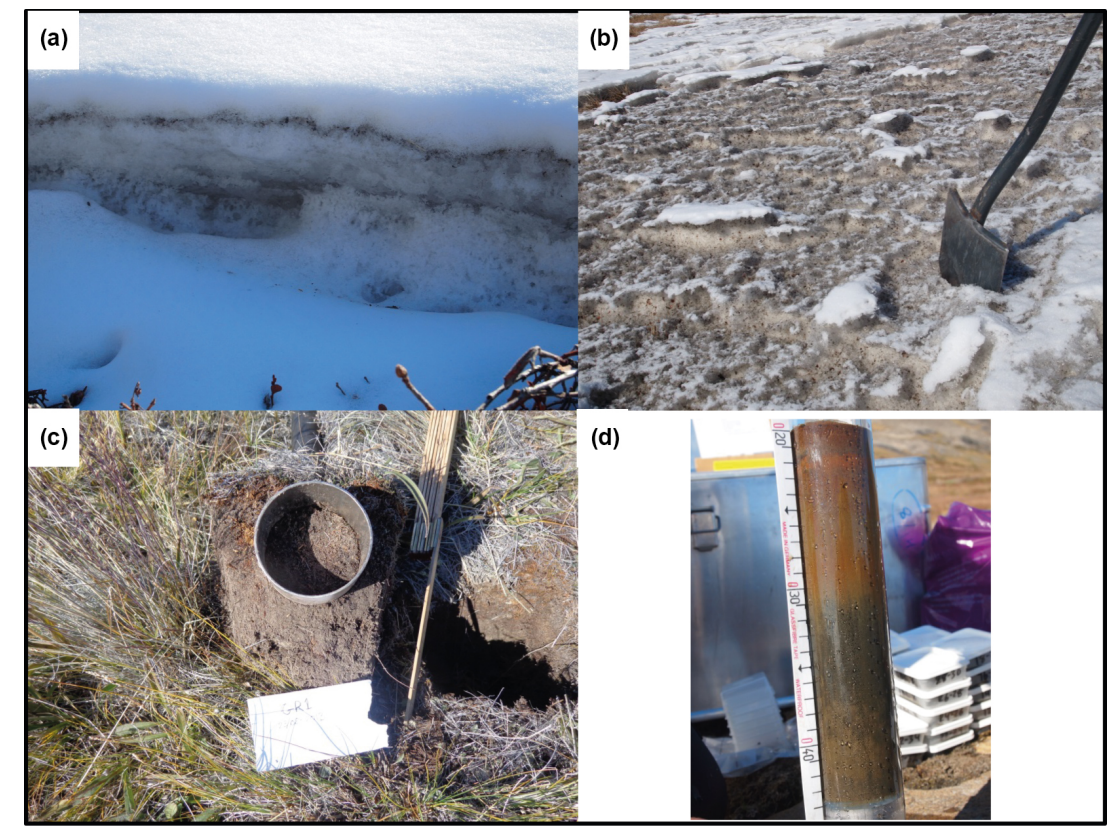

Figure 7. Photos of snow with inclusions of eolian deposits (a, b), soil sampling in steel cylinders (c) and sediment core from the lake bottom (d).

sediment surface. These loggers were also used to monitor changes in lake water level by Johansson et al. (2015a). Small variations in measurement depth were due to slight changes in the positions of the transducers following annual data retrieval and maintenance. Temperature was logged every third hour from August 2011 to August 2015.

\subsection{Precipitation and deposition}

In June and August 2013 and 2014, i.e., during all precipitation events that coincided with our sampling campaigns, precipitation samples were collected using nine white plastic pans $(34 \times 22 \times 4.5 \mathrm{~cm})$. The pans were placed on the ground close to the lake outlet (Fig. 4b) during precipitation events, and the water from each pan was mixed and transferred unfiltered to plastic flasks after $1 \mathrm{~h}$ of collection. Samples were kept frozen while awaiting analysis.

In April 2011, snow samples were collected every 10th metre along three transects using a standardised snow tube sampler ( $4.5 \mathrm{~cm}$ inner diameter; Fig. $4 \mathrm{~b})$. The collected samples were pooled and thawed, and a subsample from each transect was transferred unfiltered to a plastic flask. Samples were kept frozen while awaiting analysis.

In April 2012 and 2013, old snow packs in sheltered locations were sampled to get an estimate of the eolian deposition (Fig. 4b). In these snow packs the accumulated eolian material is clearly visible as dark layers (Fig. 7a and b). Samples were collected using a standardised snow tube (inner diameter $4.5 \mathrm{~cm}$ ), and the samples were thawed and transferred unfiltered to plastic flasks. Samples were kept frozen while awaiting analysis.

\subsection{Soils in terrestrial areas}

During installation of lysimeters in August 2011, soil samples with known volumes were collected using steel cylinders. Samples were collected at $10 \mathrm{~cm}$ depth intervals from $10 \mathrm{~cm}$ below the soil surface to the permafrost. In 2011 soil samples were also collected from different soil units using a steel spade (Fig. 4c, Soil chemistry). These soil samples were oven dried and sieved into $0-35,35-63,63-125,125-$ 250 and $>250 \mu \mathrm{m}$ fractions.

During the 2014 campaign, the top soils in areas of each vegetation type were sampled using a soil corer with a diameter of $10 \mathrm{~cm}$ (Fig. 7c). Wetland and birch types were sampled as duplicates (approximately $1 \mathrm{~m}$ apart). At each location living plants and litter were removed before sample collection, and the top $12 \mathrm{~cm}$ of the core was divided into four $3 \mathrm{~cm}$ sections and stored in plastic bags. Each sample was dried to constant weight at $35^{\circ} \mathrm{C}$, homogenised and passed through a $2 \mathrm{~mm}$ sieve to remove roots $>2 \mathrm{~mm}$; this belowground biomass was collected and weighed. In 2015, additional soil profiles were collected from two locations (triplicates) in $10 \mathrm{~cm}$ sections down to 40 or $50 \mathrm{~cm}$ soil depth. These samples were analysed as bulk samples without the removal of roots.

In August 2014, soil samples extending down into the permafrost were collected at two locations with peaty silt - one at the southern end and one in the northern end of the lake 
Table 1. The five main vegetation types and the vegetation-free barren land within the catchment area and their respective areal coverage. The number of investigated plots $(n)$ in August 2011 and short characterisations of the vegetation types are also given.

\begin{tabular}{|c|c|c|c|}
\hline Vegetation type & Area $\left(m^{2}\right)$ & $n$ & Vegetation \\
\hline Dry grassland & 231655 & 1 & $\begin{array}{l}\text { Mainly tufted species from the genus Kobresia/Carex with a } \\
\text { prominent litter layer found on exposed places. }\end{array}$ \\
\hline Meadow & 445814 & 6 & $\begin{array}{l}\text { Mainly grasses and herbs almost lacking any woody species. } \\
\text { Also some lichens and bryophytes. }\end{array}$ \\
\hline Betula & 156056 & 5 & $\begin{array}{l}\text { Birch (Betula nana) dominating in dense stands with a dominat- } \\
\text { ing litter layer on south-facing slopes and a dominating } \\
\text { bryophyte layer on north-facing slopes. }\end{array}$ \\
\hline Wetland & 83975 & 3 & $\begin{array}{l}\text { Carex and grasses dominate the field layer and bryophytes } \\
\text { cover the bottom layer. }\end{array}$ \\
\hline Salix & 6278 & 0 & $\begin{array}{l}\text { Salix dominating but kept close to ground, not reaching more } \\
\text { than a height of app. } 0.8 \mathrm{~m} .\end{array}$ \\
\hline Barren & 257431 & 0 & $\begin{array}{l}\text { Scares of exposed moraine/till, where the silt layer has been re- } \\
\text { moved by the wind. Void of vegetation. }\end{array}$ \\
\hline
\end{tabular}

using a soil coring device in steel that was driven down into the soil using a sledge hammer. At the southern end the profile extended down to $110 \mathrm{~cm}$ (not reaching the underlying till), and at the northern location it extended down to $60 \mathrm{~cm}$ and into the underlying till.

\subsection{Lake sediments}

In August 2011, surface sediment cores were collected from the centre of the lake and near the shore in the southern part of the lake using a HTH gravity corer (Renberg and Hansson, 2008). The $25 \mathrm{~cm}$ long core from the lake centre was sectioned into $1 \mathrm{~cm}$ sections down to $15 \mathrm{~cm}$ and then into $5 \mathrm{~cm}$ sections, while the $29 \mathrm{~cm}$ long core from the other location was sectioned into $5 \mathrm{~cm}$ sections throughout its entire length. All samples were placed in plastic bags and stored and transported cold. Upon arriving at the analysis laboratory the samples from the lake centre core were dried and weighted to determine the bulk density.

In August 2012, 13 additional surface sediment cores (23$40 \mathrm{~cm}$ long) were collected in four transects using a $\mathrm{KC} \mathrm{Ka-}$ jak corer (Figs. 4c, 7d). Sampling locations were selected to provide a good representation of the lakes sediments, in terms of differences in bottom type (vegetated and nonvegetated areas), location in the lake and water depth. All cores were subsectioned in the field as follows: $0-10 \mathrm{~cm}$ in $1 \mathrm{~cm}$ sections, $10-20 \mathrm{~cm}$ in $2 \mathrm{~cm}$ sections and below $20 \mathrm{~cm}$ in $4 \mathrm{~cm}$ sections. The samples were placed in plastic containers, and stored and transported cold. Upon arrival at the laboratory the samples were frozen and freeze dried.

\subsection{Biota}

\subsubsection{Terrestrial biota}

In August 2011 - during peak biomass season - the areal extents of the five main vegetation types in the TBL catch- ment (Betula, Salix, dry grassland, meadow and wetland) were determined (Table 1). The observed pattern coincided well with an orthophoto taken at the same time of the year. For each of the vegetation types (except Salix, due to a low total coverage $)$ a main plot $(0.5 \times 0.5 \mathrm{~m})$ and replicate plots $(0.2 \times 0.2 \mathrm{~m}$; not for dry grassland) were selected (Fig. $4 \mathrm{~d}$, "terrestrial primary production"). All living above-ground biomass and litter in each plot were sampled through destructive sampling. In the main plots, the living biomass was separated into functional groups (herbs/grasses, shrubs (wood and green tissue), lichens, bryophytes), whereas no separation was done in the replicate plots. Litter was separated into standing or attached to living biomass and litter found on the ground.

In late June 2014, additional biomass samples were collected from the four dominating vegetation types (Betula, dry grassland, meadow and wetland) in order to assess respiration by comparing the carbon pools in living biomass, litter and soil organic matter (see Sect. 3.4 regarding the soil sampling). For each vegetation type, three $170 \mathrm{~cm}^{2}$ circular areas within a $1 \mathrm{~m}$ by $1 \mathrm{~m}$ plot were sampled destructively for both living biomass and litter; for the Betula and wetland vegetation types, one additional replicate plot each was sampled. Similarly to the 2011 sampling, the living biomass was divided into functional groups (herbs/grasses, shrubs (wood and green tissue), lichens, bryophytes); however, in the 2014 sampling campaign litter was retained as a single functional group.

In August 2011 and 2014, a smaller number of terrestrial biota samples were collected for chemical analysis. Litter, wood and living parts of Betula, and dead parts of bryophytes were collected from different locations (Fig. 4d). Pooled samples of the dominating field layer species were collected at one location close to the northern lysimeter transect and one close to the weather station (Fig. 4d). Sampling was conducted using a pair of scissors. The northern site was 
dominated by Calamagrostis and other genus within Poaceae and Carex capillaris, with smaller contribution of Salix arctica/glauca, Vaccinium myrtillus and Carex norveica. The southern site was dominated by two species of Calamagrostis and a Poa sp., with a small contribution of Carex scirpoides. Muscle tissue from muskox (Ovibos moschatus) was also provided by a local hunter.

\subsubsection{Aquatic biota}

Water was collected with a Ruttner sampler at the lake centre for quantitative samples for phytoplankton, bacterioplankton and zooplankton (Fig. 4d). In August 2011, August 2012 and April 2012, phytoplankton and bacterioplankton samples were collected from the epilimnion (at the surface and at $5 \mathrm{~m}$ water depth) and from the hypolimnion (20 $\mathrm{m}$ water depth). In August 2011, August 2012 and June 2013, zooplankton samples were collected from $5 \mathrm{~m}$ water depth with a Ruttner sampler $(6 \mathrm{~L}$ of water was filtered through a net with $65 \mu \mathrm{m}$ mesh size). Samples for phytoplankton and zooplankton were preserved with an acidic Lugols solution according to Olrik et al. (1998), and bacterioplankton samples were preserved with formaldehyde.

In August 2011 and August 2012, benthic bacteria were sampled with a HTH-corer (diameter $8.3 \mathrm{~cm}$; Renberg and Hansson, 2008) from six locations: three deep and three shallow (Fig. 4c). The $0-1 \mathrm{~cm}$ sections of the cores were mixed, and a $1 \mathrm{~mL}$ subsample was preserved with formaldehyde. In August 2011, the areal coverage of aquatic macrophytes was mapped from a boat along six transects and by walking along the shore, and the total biomass of aquatic benthic macrophytes was estimated at 21 locations. The estimates were done by collecting, drying and weighing all macrophytes from $0.12 \mathrm{~m}^{2}$ plots (Fig. 4d). In June 2013, five additional $0.12 \mathrm{~m}^{2}$ plots were sampled in the same way from the macrophytes dive transect (see Sect. 3.6.4). In addition, biomass was quantitatively measured in nine production/respiration chambers (see Sect. 3.6.3).

In August 2012 and June 2013, benthic fauna was sampled both qualitatively and quantitatively. For the qualitative sampling, 13 samples were taken in August 2012 and 5 in June 2013 with an Ekman grabber $(16 \times 16 \mathrm{~cm})$ and sieved through $0.5 \mathrm{~mm}$. In addition to the species found in the quantitative sampling, qualitative sampling was also conducted in shallow areas using a sieve and by turning stones.

In August or September 2011, 2012 and 2014, samples of aquatic biota for chemical analysis were collected. Living tissue of vascular plants and macroalgae (Chara sp., Cladophora sp.) was collected along the lake shore. Nostoc sp. and benthic fauna (Chironomidae, Oligochaeta, Ostracoda) were sampled using an Ekman grabber. Lymnea sp., Dytiscidae, Odonata, Branchinecta paludosa and Lepidurus arcticus were sampled from the lake shore.

All biota samples were frozen before transport to the laboratory.

\subsubsection{Aquatic production/respiration measurements}

In June and August 2013, benthic production/respiration experiments were performed in plexiglas chambers with a diameter of $0.29 \mathrm{~m}$ and a volume of $0.017 \mathrm{~m}^{3}$ (volume above sediment) placed at the lake bottom. Three chambers, each at $0.7,6$ and $12 \mathrm{~m}$ water depth, were placed in June and five chambers, at $0.7 \mathrm{~m}$ depth, in August (Figs. $4 \mathrm{~d}, 5 \mathrm{c}$ and d). Oxygen and temperature were measured at the start of the incubation, after $2 \mathrm{~h}$ and at a few occasions during the following day. Primary production and respiration were calculated based on the oxygen concentration difference before and after the incubation. After the incubation, all vegetation in the chamber was sampled, dried and weighted to allow for biomass quantification (cf. Sect. 3.6.2).

In August 2012 and June 2013, pelagic production/respiration was estimated by incubating $100 \mathrm{~mL}$ glass bottles (two transparent and one dark bottle for each depth; Fig. 4d). Production of macroalgae (Chara sp. and Cladophora sp.) was also measured in $100 \mathrm{~mL}$ glass bottles in August 2012. For pelagic production/respiration measurements, glass bottles with unfiltered lake water were incubated at $0.1,0.25,0.5,1,2,3,5,10,15$ and $20 \mathrm{~m}$ water depth. For Chara sp. and Cladophora sp., pieces of algae were placed in $100 \mathrm{~mL}$ glass bottles filled with filtered $(0.45 \mu \mathrm{m})$ water from the same depths as the incubation, Chara sp. was incubated at 1, 2, 5 and $10 \mathrm{~m}$ water depth and Cladophora sp. at $5 \mathrm{~m}$ water depth. Phytoplankton, Chara sp. and Cladophora sp. were incubated for $4 \mathrm{~h}$ around midday. The oxygen concentration and temperature in the bottles were measured before and after the incubation using a HANNA HI 9146 oxygen sensor.

\subsubsection{Macrophytes inventory transect}

In June 2013 observation of spatial coverage and collection of benthic primary production biomass were conducted at the lake. (Fig. 4d). A dive survey was performed along a transect perpendicular to the depth gradient following the standard of the national environmental monitoring in Sweden (Fig. 8); see Moy et al. (2010) for a detailed description and a comparison with other methodologies. In brief, the divers started from the deeper end of the transect and followed a measuring tape towards the shoreline. Along the way, the divers noted the distance and depth together with bottom type, species composition (macrophytes) and their respective surface coverage on a seven-point scale, i.e., 1, 5, 10, 25, 50, 75 and $100 \%$ coverage. Distance, depth and species coverage were noted every time a change occurred in the bottom substrate, species composition or surface coverage. Estimation of coverage was done for a $6-10 \mathrm{~m}$ wide corridor (i.e., $3-5 \mathrm{~m}$ on each side of the tape). This resulted in a detailed description of the bottom structure, the coverage of various species and how they changed with depth and distance from the shoreline. 


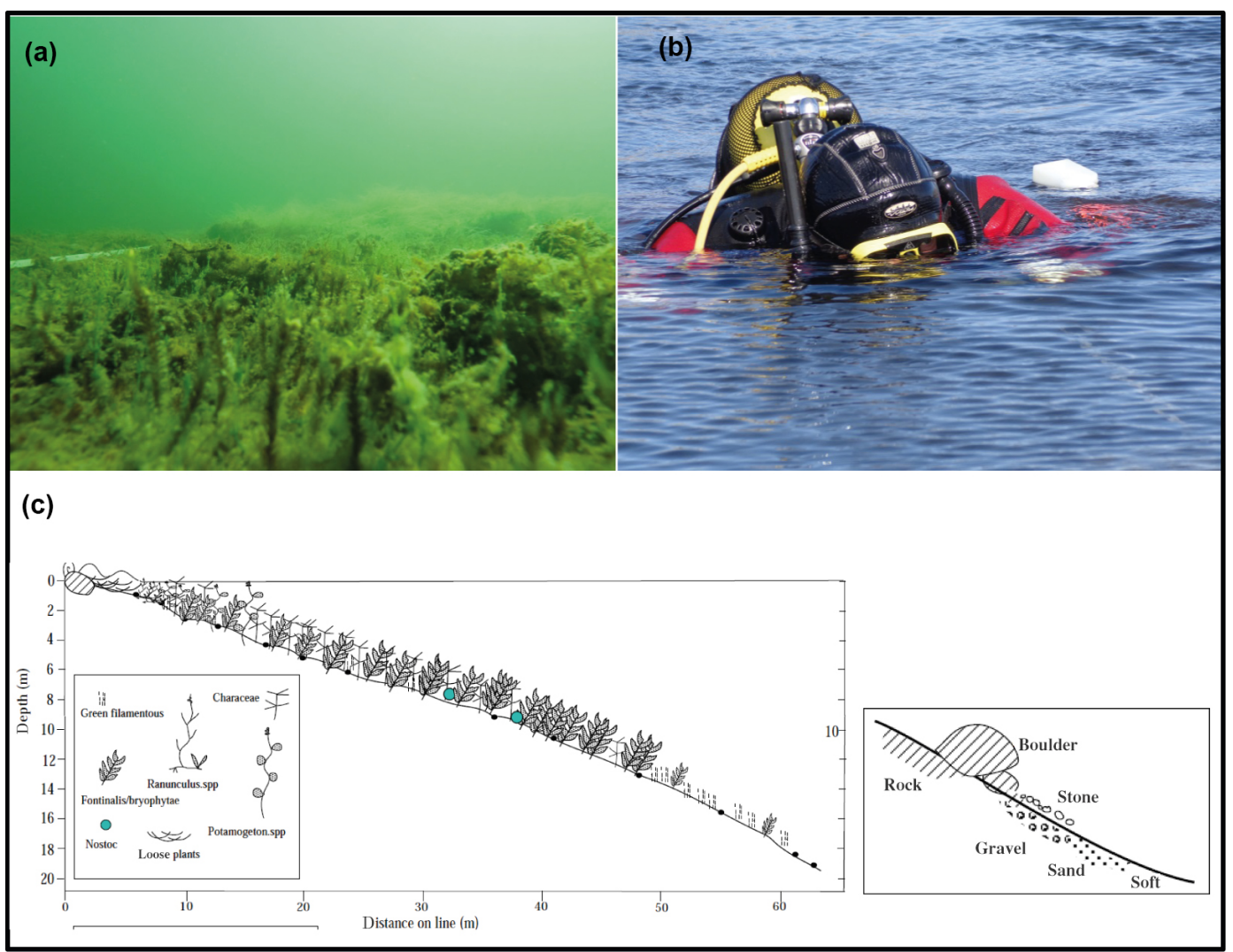

Figure 8. Photos from the macrophyte inventory (a, b) and sketches from the resulting inventory transect (c).

\section{Chemical analyses and other data processing}

\subsection{Major and trace elements in water}

The elemental concentrations of major and trace elements (Al, Ca, Fe, K, Mg, Mn, Na, P, Si, Ti, Ag, As, B, Ba, Be, $\mathrm{Cd}, \mathrm{Co}, \mathrm{Cr}, \mathrm{Cs}, \mathrm{Cu}, \mathrm{Ga}, \mathrm{Ge}, \mathrm{Hf}, \mathrm{Hg}, \mathrm{Li}, \mathrm{Mo}, \mathrm{Nb}, \mathrm{Ni}, \mathrm{Pb}, \mathrm{Rb}$, $\mathrm{S}, \mathrm{Sb}, \mathrm{Sc}, \mathrm{Se}, \mathrm{Sn}, \mathrm{Sr}, \mathrm{Ta}, \mathrm{Th}, \mathrm{Tl}, \mathrm{U}, \mathrm{V}, \mathrm{W}, \mathrm{Y}, \mathrm{Zn}, \mathrm{Zr}, \mathrm{Ce}, \mathrm{La}$, $\mathrm{Pr}, \mathrm{Nd}, \mathrm{Sm}, \mathrm{Eu}, \mathrm{Gd}, \mathrm{Tb}, \mathrm{Dy}, \mathrm{Ho}, \mathrm{Er}, \mathrm{Tm}, \mathrm{Yb}$ and Lu) in liquid samples were determined using inductively coupled plasmasector field mass spectroscopy (ICP-SFMS) (Table 2). All elements were analysed quantitatively on pre-filtered samples. Halogenes $(\mathrm{Cl}, \mathrm{Br}, \mathrm{I})$ were analysed separately under alkaline conditions. Replicate analysis $(n=8)$ shows that most elements were within either $10 \%$ or $0.01 \mu \mathrm{g} \mathrm{L}^{-1}$ (calculated as 1 standard deviation). Elements with larger deviations were $\mathrm{Cu}\left(0.6 \mu \mathrm{g} \mathrm{L}^{-1}\right), \mathrm{Fe}\left(0.3 \mu \mathrm{g} \mathrm{L}^{-1}\right), \mathrm{P}\left(0.3 \mu \mathrm{g} \mathrm{L}^{-1}\right)$, $\mathrm{Pb}\left(0.03 \mu \mathrm{g} \mathrm{L}^{-1}\right)$, Ti $\left(0.05 \mu \mathrm{g} \mathrm{L}^{-1}\right), \mathrm{W}\left(0.07 \mu \mathrm{g} \mathrm{L}^{-1}\right)$ and $\mathrm{Zn}$ $\left(0.7 \mu \mathrm{g} \mathrm{L}^{-1}\right)$.

Silica in water was analysed by allowing the silica to react with a molybdate reagent, reduced by ascorbic acid to form molybdenum blue and quantified using segmented flow analysis (SFA) following the procedure outlined in OI Analytical methodology part no. 319529. In a small number of samples, the concentrations of halogens $\left(\mathrm{Br}^{-}, \mathrm{Cl}^{-}, \mathrm{F}^{-}\right)$and sulfate $\left(\mathrm{SO}_{4}^{2-}\right)$ were determined using liquid ion chromatography (DIN EN ISO 10304-1/-2; Table 2).

Elemental concentrations of $\mathrm{Al}, \mathrm{Ca}, \mathrm{Fe}, \mathrm{K}, \mathrm{Mg}, \mathrm{Mn}, \mathrm{Na}, \mathrm{P}$, $\mathrm{Si}$, Ti, Ag, As, B, Ba, Be, Cd, Co, Cr, Cs, Cu, Ga, Ge, Hf, $\mathrm{Hg}, \mathrm{Li}, \mathrm{Mo}, \mathrm{Nb}, \mathrm{Ni}, \mathrm{Pb}, \mathrm{Rb}, \mathrm{S}, \mathrm{Sb}, \mathrm{Sc}, \mathrm{Se}, \mathrm{Sn}, \mathrm{Sr}, \mathrm{Ta}, \mathrm{Th}$, Tl, U, V, W, Y, Zn, Zr, Ce, La, Pr, Nd, Sm, Eu, Gd, Tb, Dy, $\mathrm{Ho}, \mathrm{Er}, \mathrm{Tm}, \mathrm{Yb}$ and $\mathrm{Lu}$ in suspended solids trapped on acid washed filters $(0.22 \mu \mathrm{m})$ were determined using ICP-SFMS (Table 2). The filters and suspended solids were digested in strong acid $\left(\mathrm{HNO}_{3}: \mathrm{HF}\right)$ in closed Teflon vessels (losses might occur for elements denoted in italic). Concentrations in suspended solids were corrected for dissolved substances by including the analysis of filters soaked in pre-filtered water and are reported as $\mu \mathrm{g} \mathrm{L}^{-1}$.

\subsection{Major and trace elements in solid samples}

Major and trace elements in solid samples were analysed using either wavelength dispersive $\mathrm{X}$-ray fluorescence spectroscopy (WD-XRF) on loose-powder samples, following the method described by Rydberg (2014), or ICP-SFMS, following either digestion (total concentrations) or leaching (extractable concentrations) (Table 2). All samples analysed using WD-XRF were pulverised using a Retsch swing mill $(2 \mathrm{~min}$ at $30 \mathrm{~Hz})$ prior to analysis. 
Table 2. Overview of the laboratories and analytical methods that have been used to produce the presented data set.

\begin{tabular}{|c|c|c|c|c|}
\hline Parameter & $\begin{array}{l}\text { Sample } \\
\text { type }\end{array}$ & & Laboratory - analytical method & \\
\hline Organic content & Solid & EMG, UmU - LOI & SLU, Uppsala - LOI & ALS Scandinavia - LOI \\
\hline Tot-C & Solid & SLU, Umeå - EA-IRMS & SLU, Uppsala - EA & ALS Scandinavia - EA \\
\hline TOC, DOC & Water & DEEP, SU - NPOC & ALS Scandinavia - NPOC/TC-IC & \\
\hline TIC, DIC & Water & DEEP, SU - IR after acidification & ALS Scandinavia - IR after acidification & \\
\hline$\delta^{13} \mathrm{C}$ & $\begin{array}{l}\text { Solid } \\
\text { Water }\end{array}$ & $\begin{array}{l}\text { SLU, Umeå - EA-IRMS } \\
\text { IGV, SU - IRMS }\end{array}$ & ISO-Analytical - EA-IRMS & \\
\hline Tot-N & $\begin{array}{l}\text { Solid } \\
\text { Water }\end{array}$ & $\begin{array}{l}\text { SLU, Umeå - EA-IRMS } \\
\text { DEEP, SU - SFA }\end{array}$ & $\begin{array}{l}\text { SLU, Uppsala - EA } \\
\text { ALS Scandinavia - CFA }\end{array}$ & ALS Scandinavia - EA \\
\hline $\mathrm{NH}_{4}^{+}, \mathrm{NO}_{2}^{-}, \mathrm{NO}_{3}^{-}$ & $\begin{array}{l}\text { Solid } \\
\text { Water }\end{array}$ & $\begin{array}{l}\text { ALS Scandinavia - IC } \\
\text { DEEP, SU - SFA }\end{array}$ & ALS Scandinavia - CFA & \\
\hline$\delta^{15} \mathrm{~N}$ & Solid & SLU, Umeå - EA-IRMS & ISO-Analytical - EA-IRMS & \\
\hline Tot-P & $\begin{array}{l}\text { Water } \\
\text { Filters }\end{array}$ & $\begin{array}{l}\text { DEEP, SU - SFA } \\
\text { DEEP, SU - combustion SFA }\end{array}$ & & \\
\hline $\mathrm{PO}_{4}^{3-}$ & $\begin{array}{l}\text { Solid } \\
\text { Water }\end{array}$ & $\begin{array}{l}\text { ALS Scandinavia - CFA } \\
\text { DEEP, SU - SFA }\end{array}$ & & \\
\hline Chlorophyll $a$ & Filters & DEEP, SU - spectrometry & & \\
\hline $\begin{array}{l}\text { Major }+ \\
\text { trace elements }\end{array}$ & $\begin{array}{l}\text { Solid } \\
\text { Water }\end{array}$ & $\begin{array}{l}\text { EMG, UmU - WD-XRF } \\
\text { ALS Scandinavia - ICP-SFMS }\end{array}$ & ALS Scandinavia - ICP-SFMS & \\
\hline $\mathrm{Si}$ & Water & DEEP, SU - SFA & & \\
\hline $\mathrm{Br}^{-}, \mathrm{Cl}^{-}, \mathrm{F}^{-}$ & $\begin{array}{l}\text { Solid } \\
\text { Water }\end{array}$ & $\begin{array}{l}\text { ALS Scandinavia - IC (F only) } \\
\text { ALS Scandinavia - IC }\end{array}$ & & \\
\hline $\mathrm{SO}_{4}^{2-}$ & $\begin{array}{l}\text { Solid } \\
\text { Water }\end{array}$ & $\begin{array}{l}\text { ALS Scandinavia - IC } \\
\text { ALS Scandinavia - IC }\end{array}$ & & \\
\hline$\delta^{34} S$ & Water & IGV, SU - EA-IRMS & & \\
\hline$\delta^{2} \mathrm{H}$ & Water & $\begin{array}{l}\text { SLU, Umeå - liquid water } \\
\text { isotope analyzer }\end{array}$ & & \\
\hline$\delta^{18} \mathrm{O}$ & Water & $\begin{array}{l}\text { SLU, Umeå - liquid water } \\
\text { isotope analyzer }\end{array}$ & & \\
\hline${ }^{234} \mathrm{U}:{ }^{235} \mathrm{U}$ & Water & FOI - ICP-SFMS & & \\
\hline${ }^{14} \mathrm{C}$ & Solid & ${ }^{14} \mathrm{C}$ dating laboratory, $\mathrm{LU}-\mathrm{AMS}$ & & \\
\hline $\begin{array}{l}{ }^{210} \mathrm{~Pb},{ }^{137} \mathrm{Cs} \\
{ }^{226} \mathrm{Ra} \text { etc. }\end{array}$ & Solid & $\begin{array}{l}\text { Flett Research - alpha } \\
\text { spectroscopy ( }{ }^{210} \mathrm{~Pb} \text { only) }\end{array}$ & Nutech, DTU - gamma spectroscopy & \\
\hline
\end{tabular}

Total concentrations were determined following either lithium borate $\left(\mathrm{LiBO}_{2}\right)$ fusion $(\mathrm{Al}, \mathrm{Ba}, \mathrm{Be}, \mathrm{Ca}, \mathrm{Ce}, \mathrm{Cr}, \mathrm{Dy}$, Er, Eu, Fe, Ga, Gd, Hf, Ho, K, La, Lu, Na, Nb, Nd, P, Pr, Rb, Sc, Si, Sm, Sr, Ta, Tb, Th, Ti, Tm, U, W, V, Y, Tb, Zr), strong acid $\left(\mathrm{HNO}_{3}: \mathrm{HF}\right)$ digestion (Ag, As, $\mathrm{Au}, \mathrm{B}, \mathrm{Bi}, \mathrm{Cd}, \mathrm{Co}, \mathrm{Cs}$, $\mathrm{Cu}, \mathrm{Hg}$, Ir, Li, Mo, Ni, Os, Pb, Pd, Pt, Re, Rh, Ru, S, Sb, Se, $\mathrm{Sn}, \mathrm{Te}, \mathrm{Tl}, \mathrm{Zn}$ ) or sintering at $550{ }^{\circ} \mathrm{C}$ with $\mathrm{ZnO}$ and $\mathrm{NaCO}_{3}$
$(\mathrm{Cl}, \mathrm{Br}, \mathrm{I})$. For the analysis of extractable metals, the samples were leached in ammonium acetate solution $\left(\mathrm{NH}_{4} \mathrm{Ac}\right.$ $\mathrm{CH}_{4} \mathrm{COO}$ ) buffered to $\mathrm{pH} 4.5$ for $16 \mathrm{~h}$. Methane was added to enhance the analytical performance for $\mathrm{Ag}$ and $\mathrm{Pd}$, and halogens $(\mathrm{Cl}, \mathrm{Br}, \mathrm{I})$ were analysed separately in an alkaline environment. For samples analysed in 2011-2013, Al, As, $\mathrm{Ba}, \mathrm{Be}, \mathrm{Br}, \mathrm{Ca}, \mathrm{Cd}, \mathrm{Cl}, \mathrm{Co}, \mathrm{Cr}, \mathrm{Cs}, \mathrm{Cu}, \mathrm{Fe}, \mathrm{I}, \mathrm{K}, \mathrm{Li}, \mathrm{Mg}$, 
Mn, Mo, Na, Nb, Ni, P, Pb, Pd, S, Se, Si, Sn, Sr, Ti, U, V and $\mathrm{Zn}$ were analysed quantitatively, while the remaining elements were analysed semi-quantitatively (i.e., the reported data are based on the relative analytical response for the element; however, because the response is not fully calibrated it only represents a relative measure of the concentration). In 2014, all elements were analysed quantitatively.

For the WD-XRF analysis, lower limits of detection range from a few $\mu \mathrm{g} \mathrm{g}^{-1}$ for trace elements to a few tens of $\mu \mathrm{g} \mathrm{g}^{-1}$ for major elements. Accuracy was assessed using 10 different certified reference materials $(n=5)$ and were within $\pm 10 \%$ (or a few $\mu \mathrm{g} \mathrm{g}^{-1}$ ) for all elements except $\mathrm{S}$, which had an accuracy of about 20\% (Rydberg, 2014). Precision, based on replicate measurements of TBL samples $(n=30)$, was always better than $5 \%$ (or $\pm 1 \mu \mathrm{g} \mathrm{g}^{-1}$ for elements present in low concentrations). Fluoride $\left(\mathrm{F}^{-}\right)$and sulfate $\left(\mathrm{SO}_{4}^{2-}\right)$ in solid samples were analysed by liquid ion chromatography (Table 2), following the procedure outlined in DIN EN ISO 10304-1.

\subsection{Carbon and nutrients in water}

Organic carbon (OC), inorganic carbon (IC), nitrogen (total $\mathrm{N}, \mathrm{NH}_{4}-\mathrm{N}, \mathrm{NO}_{2}+\mathrm{NO}_{3}-\mathrm{N}$ ) and phosphorus (total $\mathrm{P} ; \mathrm{PO}_{4}-$ $\mathrm{P}$ ) in water samples were analysed (Table 2). Total organic carbon (TOC) and dissolved organic carbon (DOC) were determined by thermal combustion $\left(680^{\circ} \mathrm{C}\right)$ following acidification (to remove any IC), while IC was analysed by converting all IC to $\mathrm{CO}_{2}$ in a reactor vessel filled with $25 \% \mathrm{H}_{3} \mathrm{PO}_{4}$ (AnalyticJena Multi N/C-3100).

Nitrogen and phosphorus, as well as their different species, were determined using SFA following the procedures outlined in OI Analytical methodology part no. $319526\left(\mathrm{NH}_{4}-\right.$ $\mathrm{N}$ ), no. 319527 (total N, $\mathrm{NO}_{2}+\mathrm{NO}_{3}-\mathrm{N}$ ) and no. 319528 (total $\left.\mathrm{P}, \mathrm{PO}_{4}-\mathrm{P}\right)$. The reported analytical uncertainty was less than $10 \%$. Total C, TOC, DOC, total inorganic carbon (TIC) and dissolved inorganic carbon (DIC) were analysed following the procedures outlined in DIN EN ISO 1484-H3. Total $\mathrm{N}$ analysis was made after oxidative digestion with peroxydisulfate (DIN EN ISO 11905-1:1997), $\mathrm{NO}_{3}-\mathrm{N}$ was analysed through ion chromatography (DIN EN ISO 103041/-2-D19) and $\mathrm{NO}_{2}-\mathrm{N}$ and $\mathrm{NH}_{4}-\mathrm{N}$ were analysed through continuous-flow analysis and spectrometric detection (DIN EN ISO 13395-D28 and DIN EN ISO 11732-E23, respectively).

In addition to the total and dissolved concentrations described above, chlorophyll $a(\mathrm{Chl} a)$ and phosphorus associated with the particulate fraction were analysed (Table 2). In brief, known volumes of water were filtered through $0.45 \mu \mathrm{m}$ cellulose acetate filters. For Chl $a$ analysis the Chl $a$ was extracted from the filters using ethanol (96\%) and the Chl $a$ concentration in the solution was measured using a spectrophotometer (Helcom Combine manual; Helcom, 2016, Annex C-4) and phosphorus on the filters was determined using SFA following combustion (OI Analytical methodology part no. 319528). The reported analytical uncertainty was $25 \%$ for the Chl $a$ measurements and less than $5 \%$ for $\mathrm{C}$, $\mathrm{N}$ and $\mathrm{P}$.

\subsection{Organic material and nutrients in solid samples}

The organic contents of solid samples were estimated by either total carbon analysis or loss on ignition (LOI). A smaller number of soil samples were analysed using both approaches to allow for comparison between the two methods. Total carbon and nitrogen concentrations were determined either separately using an elemental analyser or simultaneously as the analysis of stable $\mathrm{C}$ and $\mathrm{N}$ isotopes (see further details below; Table 2).

By comparing the carbon contents in acid-treated samples with those in samples not treated with acid, Rydberg et al. (2016) concluded that inorganic carbon contents in the sediments of TBL are negligible, implying that total carbon in the sediment equals total organic carbon. LOI samples were first dried at $105^{\circ} \mathrm{C}$ to constant weight, then burnt in a muffle furnace at $550^{\circ} \mathrm{C}$ for $4 \mathrm{~h}$ and reweighed.

Nitrate and phosphate in solid samples were determined following the procedure outlined in DIN EN ISO 10304-1/2-D19/20 and DIN EN ISO 15681-2 (D46), respectively.

\subsection{Stable isotopes}

Carbon, nitrogen and their stable isotopes in solid samples were determined simultaneously using an elemental analyser coupled with an isotope-ratio mass spectrometer (EAIRMS) (Table 2). The data were corrected for instrumental drift and sample-size effects using internal standards, and $\delta^{13} \mathrm{C}$ and $\delta^{15} \mathrm{~N}$ were calculated with reference to Vienna Pee Dee Belemnite (VPDB) and atmospheric air, respectively. Analytical performance was assessed using different internal standards that are regularly checked against certified reference materials. The standard deviation of all internal standards ( $n=42$ and $n=10$ for SLU and ISO-Analytical, respectively) were always less than $\pm 0.7 \%$ for $\mathrm{C}, \pm 0.3 \%$ o for $\delta^{13} \mathrm{C}, \pm 0.1 \%$ for $\mathrm{N}$ and $\pm 0.2 \%$ for $\delta^{15} \mathrm{~N}$ for SLU and less than $\pm 2.5 \%$ for $\mathrm{C}, \pm 0.1 \%$ or $\delta^{13} \mathrm{C}, \pm 0.4 \%$ for $\mathrm{N}$ and $\pm 0.2 \%$ ofor $\delta^{15} \mathrm{~N}$ for ISO-Analytical Ltd.

In all water samples stable carbon isotopic composition in DIC was determined by injecting $5 \mathrm{~mL}$ of water into $12 \mathrm{~mL}$ septum-sealed glass vials in the field (Table 2). The glass vials had been prefilled with $100 \mu \mathrm{L}$ of $85 \% \mathrm{H}_{3} \mathrm{PO}_{4}$ and flushed with helium gas $\left(100 \mathrm{~mL} \mathrm{~min}^{-1}\right)$ for $5 \mathrm{~min}$, and the isotopic composition of the head space was determined using a Gasbench II coupled to a continuous-flow IRMS (Thermo scientific MAT 253). The isotopic composition, $\delta^{13} \mathrm{C}$, was calculated with reference to VPDB, and the reproducibility of the analysis was reported to be better than $0.1 \%$.

Analyses of hydrogen and oxygen isotopes in water samples were conducted using a liquid water isotope analyser (Picarro L1102-i). The $\delta^{18} \mathrm{O}$ and $\delta^{2} \mathrm{H}$ values were calculated 


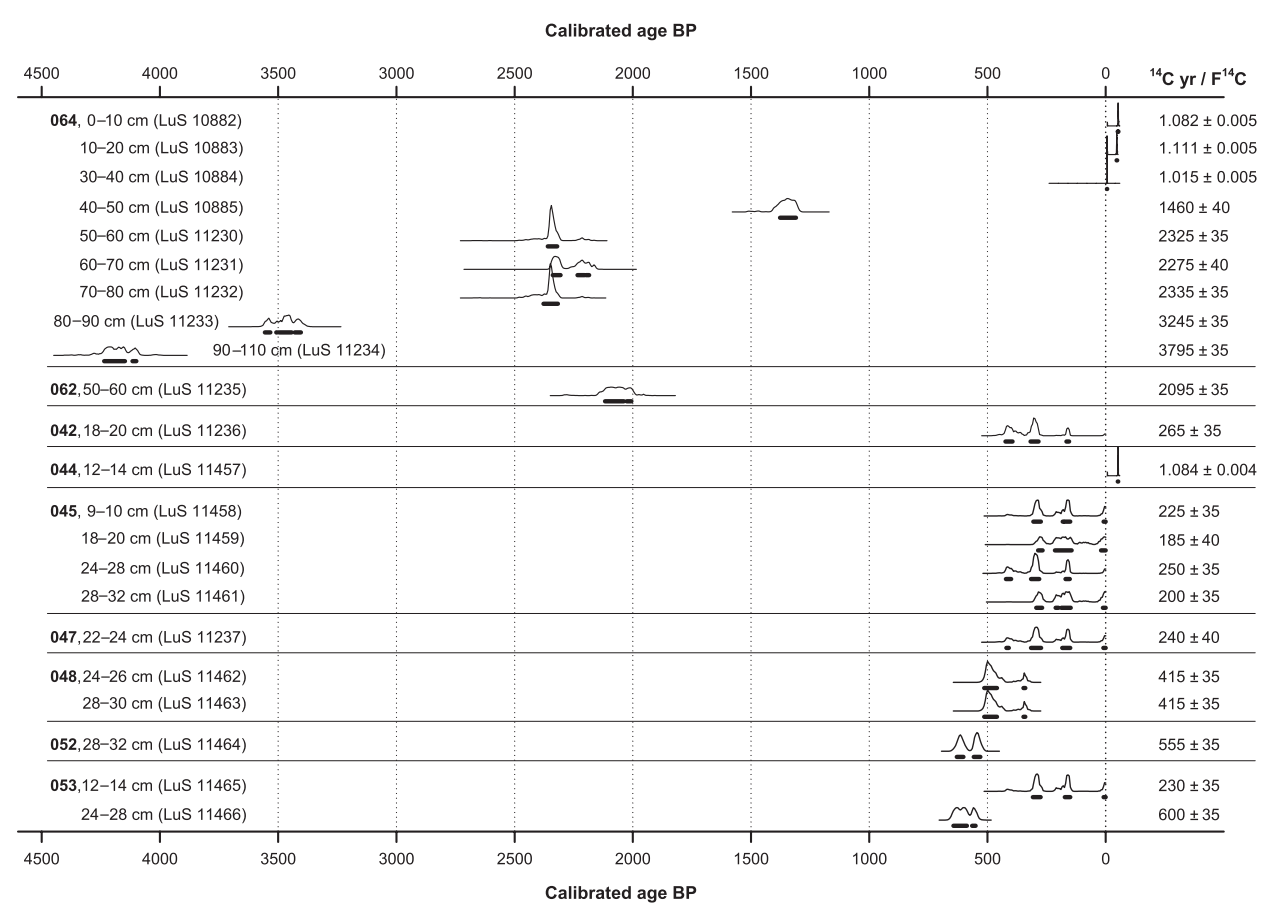

Figure 9. Calibrated age distributions for all ${ }^{14} \mathrm{C}$ dated soil and sediment samples. The thin line represents the probability distribution for each respective sample, and the thick black line shows the $1 \sigma$ age distributions. The column to the left gives the sample name followed by the laboratory sample number, while the numbers to the right are the uncalibrated ${ }^{14} \mathrm{C}$ dates (or $\mathrm{F}^{14} \mathrm{C}$ values for samples with a modern carbon composition) with their respective error estimates.

with reference to Vienna Standard Mean Ocean Water (VSMOW), and the reported analytical uncertainties for $\delta^{18} \mathrm{O}$ and $\delta^{2} \mathrm{H}$ were 0.065 and $0.0280 \%$, respectively.

Sulfur-34 $\left({ }^{34} \mathrm{~S}\right)$ and sulfur-32 $\left({ }^{32} \mathrm{~S}\right)$ were determined. The samples were precipitated as $\mathrm{BaSO}_{4}$ and then analysed using an EA-IRMS system (a Carlo Erba NC2500 connected to a Thermo Delta plus). The isotopic composition, $\delta^{34} \mathrm{~S}$, was calculated with reference to Vienna-Canyon Diablo Troilite (VCDT), and the reproducibility of the analysis was calculated to be better than $0.2 \%$.

\subsection{Radioisotopes}

The soil, permafrost and sediment samples were analysed for carbon-14 $\left({ }^{14} \mathrm{C}\right)$ (Table 2). The samples were converted to graphite using an automated graphitisation equipment (AGE) and then analysed for their ${ }^{14} \mathrm{C}$ content using single stage accelerator mass spectrometry (AMS). The values reported in the database are either uncalibrated ${ }^{14} \mathrm{C}$ ages or the fraction of modern carbon $\left(\mathrm{F}^{14} \mathrm{C}\right)$ for post-bomb dates. Calibrated ages were obtained using either the InterCal13.14C or the region-1 post-bomb curve (Reimer et al., 2013; Hua et al., 2013) in the online version of Oxcal 4.2 (https://c14.arch.ox. ac.uk; Bronk Ramsey, 2009) and are shown in Fig. 9.

Lead-210 $\left({ }^{210} \mathrm{~Pb}\right)$ was analysed either measuring the activity of its daughter isotope polonium-210 $\left({ }^{210} \mathrm{Po}\right)$ by means of alpha spectrometry or as a direct measurement together with cesium-137 $\left({ }^{137} \mathrm{Cs}\right)$, radium-226 $\left({ }^{226} \mathrm{Ra}\right)$, thorium$232\left({ }^{232} \mathrm{Th}\right)$, thallium-208 $\left({ }^{208} \mathrm{Tl}\right)$, potassium-40 $\left({ }^{40} \mathrm{~K}\right)$ and americium-241 $\left({ }^{241} \mathrm{Am}\right)$, using gamma spectroscopy (Table 2). Alpha spectrometry measurements were conducted using between 0.25 and $0.5 \mathrm{~g}$ of sample and a counting time of $60000 \mathrm{~s}$. The method detection limit was estimated to 0.1$0.2 \mathrm{DPM} \mathrm{g}^{-1}$ (disintegrations/time), the counting errors were generally less than $10 \%$ (except for very low ${ }^{210}$ Po activities), and replicate analysis $(n=6)$ deviated less than 0.1 disintegrations per minute $g^{-1}$. The gamma spectrometry was conducted using 5-23g of sample and a counting time between 83000 and $340000 \mathrm{~s}$. The reported uncertainty of the analysis varies between 6 and $30 \%$ depending on the specific radioisotope and the activity of the specific samples (lower activities generally have higher relative uncertainty).

The uranium-234:235 $\left({ }^{234} \mathrm{U}:{ }^{235} \mathrm{U}\right)$ isotopic ratio measurements were conducted by allowing $1 \mathrm{~L}$ of water to desiccate. The residue was then digested using $2 \% \mathrm{HNO}_{3}$ and the ${ }^{234} \mathrm{U}:{ }^{235} \mathrm{U}$ ratio was determined using ICP-SFMS. The analytical performance was assessed using certified reference materials and the reported uncertainties (95\% confidence interval) were below $5 \%$, except for the Pingo spring sample that had an uncertainty of $30 \%$. The Pingo spring is located outside of the focus area, close to a meltwater outlet from the ice sheet and not representative for the TBL catchment. 


\subsection{Biomass quantification}

\subsubsection{Terrestrial}

For the main plots in the 2011 biomass sampling and all plots in the 2014 biomass sampling, the living biomass of each functional group - herbs/grasses, shrubs, lichens, mosses and two litter types (2011 only) - was determined by subtracting the moisture content, determined by drying subsamples at $80^{\circ} \mathrm{C}$, from the total sample weight. The weight of attached mineral grains was also corrected for by analysing LOI (loss on ignition) in subsamples. In the replicate plots from the 2011 biomass sampling, the same approach was employed to obtain the total biomass samples. The litter biomass in the 2011 replicate plots and all 2014 biomass sampling plots was estimated by using the ratio between living biomass and litter from the main plots in the 2011 biomass sampling.

\subsubsection{Aquatic}

The species composition and biovolumes of phytoplankton and zooplankton were determined using an inverted phasecontrast microscope, and samples were allowed to settle overnight. For phytoplankton, the carbon biomass was estimated by assuming a wet weight of $1 \mathrm{~g} \mathrm{~cm}^{-3}$ and using the taxa-specific carbon-content conversion factors presented by Olrik et al. (1998). For zooplankton, carbon biomass was estimated using length-to-weight conversion factors (Johansson et al., 1976; Ruttner-Kolisko, 1977) and assuming a conversation factor of dry weight (DW) to carbon of 0.48 .

Both planktonic and benthic bacteria samples were analysed. The benthic samples were first sonicated at $75 \mathrm{~W}$ for one minute. All samples were stained with acridine orange, filtered onto $0.2 \mu \mathrm{m}$ polycarbonate filters and counted using an epifluorescence microscope. A total of at least 400 cells were counted for each sample, and total biovolumes were estimated by measuring at least 100 cells. DW was calculated according to Loferer-Krössbacher et al. (1998) using Eq. (1):

dry weight $=435 \times$ volume $^{0.86}$.

The carbon content was estimated assuming a dry-weight-tocarbon conversion factor of 0.5 .

The total mass of aquatic macrophytes was converted to carbon biomass by assuming a dry-weight-to-carbon conversion factor of 0.4. Biomass for benthic fauna was calculated by assuming that the DW was $20 \%$ of the wet weight, and the carbon content was estimated by assuming a dry-weightto-carbon conversion factor of 0.3 (Kautsky, 1995).

\section{Results}

\subsection{Precipitation and deposition}

Concentrations of TOC/DOC (TOC or DOC), total nitrogen and phosphorus in precipitation showed considerable variation depending on precipitation type (Fig. 10). Newly fallen snow, as well as filtered samples, had very low TOC/DOC, nitrogen and phosphorus concentrations (1-3, 0.3-1 and 33-83 $\mu \mathrm{g} \mathrm{L}^{-1}$, respectively), whereas unfiltered old snow that also contained large amounts of eolian material - had much higher concentrations (40-60, 3-4 $\mathrm{mg} \mathrm{L}^{-1}$ and 1400$2700 \mu \mathrm{g} \mathrm{L}^{-1}$, respectively). There was also a difference in the $\delta^{18} \mathrm{O}$ and $\delta^{2} \mathrm{H}$ between rain and snow, with rain having slightly higher values (Fig. 11). As an example of major and trace elements we have chosen to plot the concentrations of aluminium (i.e., a lithogenic element involved in few biological processes), silicon (i.e., a lithogenic element that is an important constituent of, e.g., diatom valves and some sedges) and copper (i.e., a trace element that is an important micronutrient and that binds readily to organic matter). The concentrations of all these elements were low or very low in both rainwater and snow. In rainwater the aluminium, silicon and copper concentrations were 3-8, 0.008-0.01 and $1-7 \mathrm{mg} \mathrm{L}^{-1}$, respectively, while in snow the concentrations were $0.3-176,0.01-0.05$ and $0.5-4 \mathrm{mg} \mathrm{L}^{-1}$ for aluminium, silicon and copper, respectively (Fig. 12).

\subsection{Soil water}

Deep soil water (samples from lysimeters and soil water wells) and surface water (puddles and small inlets) showed relatively similar TOC/DOC, nitrogen and phosphorus concentrations $\left(21-37,0.9-1.5 \mathrm{mg} \mathrm{L}^{-1}\right.$ and $10-50 \mu \mathrm{g} \mathrm{L}^{-1}$, respectively; Fig. 10). Because the TOC/DOC values for the unfiltered samples were virtually identical, it was concluded that all organic carbon was present in the dissolved phase (i.e., TOC equals DOC; Fig. 10). Even if deeper soil water samples showed considerable variation in DIC concentrations, they were generally higher as compared to the DIC concentrations in surface waters (Fig. 10). $\delta^{18} \mathrm{O}$ and $\delta^{2} \mathrm{H}$ values in soil water overlapped with the values for precipitation, while $\delta^{13} \mathrm{C}$ in DIC was more depleted in the heavy isotope in deep soil water as compared to surface water (Fig. 11). The concentrations for aluminium $\left(12-2709 \mathrm{mg} \mathrm{L}^{-1}\right)$, silicon (0.02-2 $\left.\mathrm{mg} \mathrm{L}^{-1}\right)$ and copper (1-225 $\left.\mathrm{mg} \mathrm{L}^{-1}\right)$ were noticeably higher in soil water as compared to precipitation (Fig. 12).

\subsection{Lake water}

Lake water temperature at $4 \mathrm{~m}$ depth varied between 1 and $14{ }^{\circ} \mathrm{C}$, with maximum temperatures occurring in late July or early August (Fig. 13). Similar to the soil water samples, there were very small differences in TOC/DOC between unfiltered and filtered samples, and there were also only minor differences in TOC/DOC, nitrogen and phosphorus between surface and bottom waters (Fig. 10). TOC/DOC, nitrogen and phosphorus concentrations in lake water samples were lower than those in the soil water samples $(8-10,0.5-$ $0.9 \mathrm{mg} \mathrm{L}^{-1}$, and 3-11 $\mu \mathrm{g} \mathrm{L}^{-1}$, respectively; Fig. 10), while DIC concentrations in lake water $\left(14-21 \mathrm{mg} \mathrm{L}^{-1}\right)$ were in 


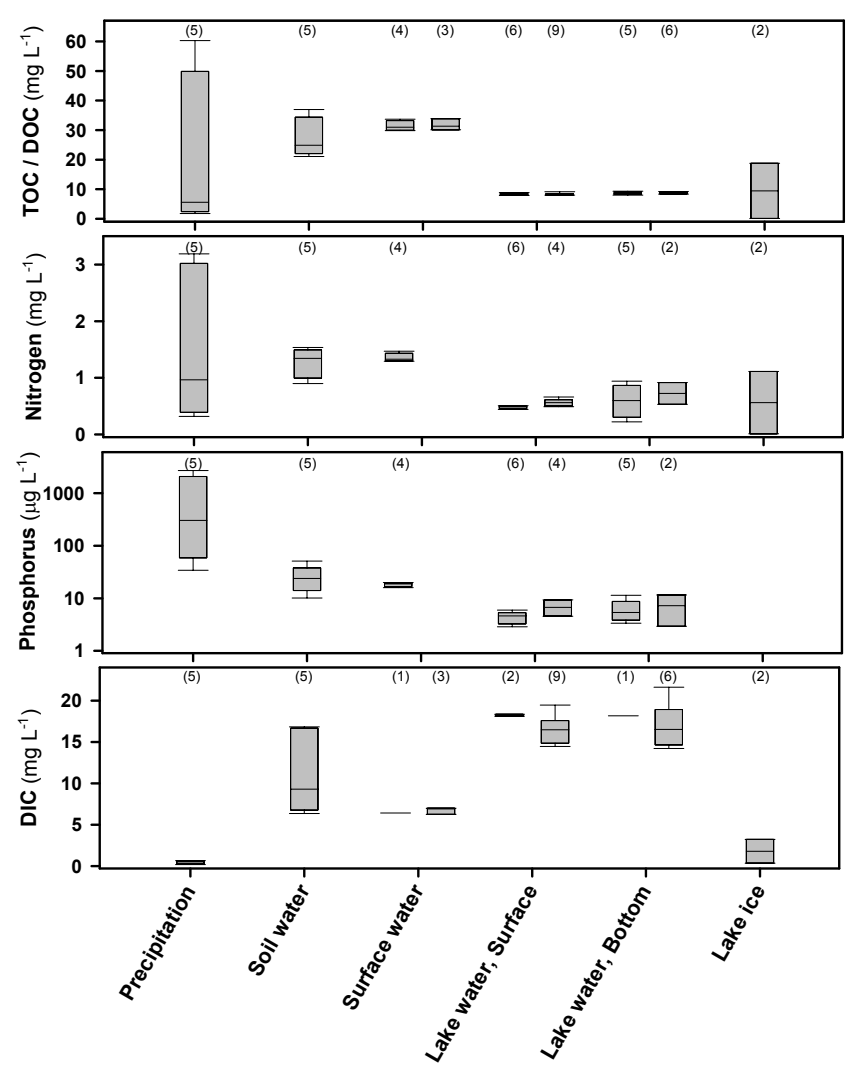

Figure 10. Box plot showing the concentrations of TOC/DOC, total nitrogen, total phosphorus and DIC in water samples from different catchment compartments. For surface and lake water, the box to the left represents unfiltered samples, while the box to the right represents filtered samples. The boxes denote the median and the 25th and 75th percentiles, while the whiskers denote the 10th and 90th percentiles. The numbers within parenthesis represent the number of samples for each sample type.

the upper range of those measured in soil water samples (6$16 \mathrm{mg} \mathrm{L}^{-1}$; Fig. 10). $\delta^{18} \mathrm{O}$ and $\delta^{2} \mathrm{H}$ plot in a very narrow range in the uppermost range of the results for precipitation and soil water, while $\delta^{13} \mathrm{C}$ in lake water DIC was considerably less depleted in the heavy isotope than in all other catchment compartments (Fig. 11). Lake water had the lowest concentrations of aluminium, silicon and copper of all sampled ecosystem compartments. Silicon was below the detection limit in all samples, whereas aluminium and copper concentrations were $0.5-3$ and $1-2 \mathrm{mg} \mathrm{L}^{-1}$, respectively (Fig. 12).

Results from the in situ measurements of dissolved oxygen and temperature (Fig. 13) show the highest oxygen concentrations in the end of the autumn. During winter, a sharp decrease in dissolved oxygen is observed at $17-20 \mathrm{~m}$ depth, whereas the oxygen level at 5-8 $\mathrm{m}$ depth is relatively stable the whole winter period. During summer the oxygen concentrations decrease slightly both at shallow and greater depths as the lake temperature rises.

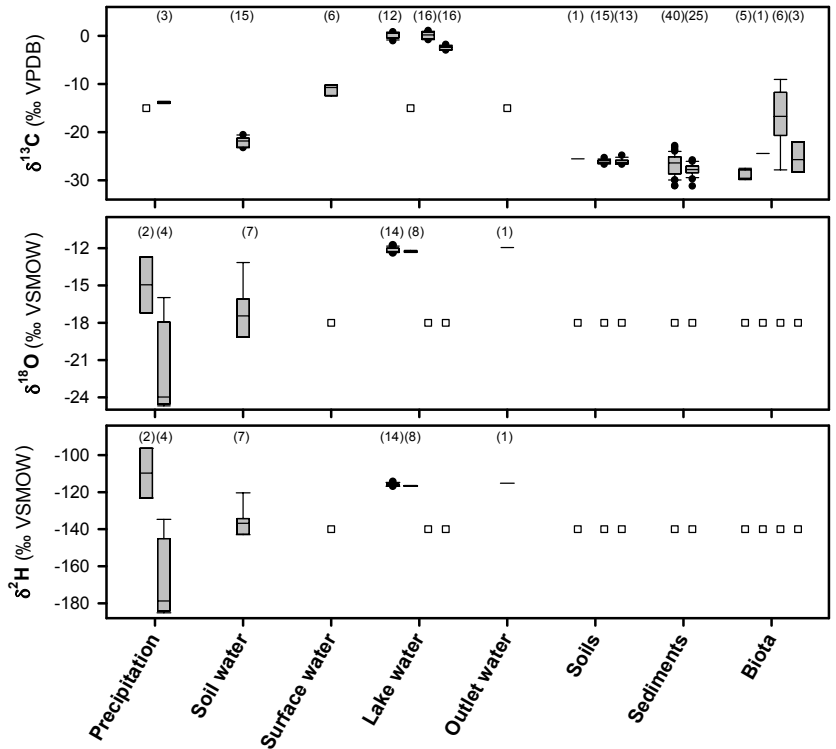

Figure 11. Box plot showing the isotopic composition of carbon, oxygen and hydrogen in different sample types. For water samples the $\partial^{13} \mathrm{C}$ is determined on DIC only, while for solid samples the measurements were made on total carbon. The two boxes for precipitation represent rain (left) and snow (right). The four boxes for lake water represent (from left to right) surface and bottom water from locations other than the lake centre and surface and bottom water from the lake centre. The three boxes for soils represent silt (left), peaty-silt active layer (middle) and peaty-silt permafrost (right). The two boxes for sediments represent samples collected from water depths $<14 \mathrm{~m}$ (left) and $>14 \mathrm{~m}$ (right), respectively. The four boxes for biota represent (from left to right) terrestrial primary producers, terrestrial consumers, aquatic primary producers and aquatic consumers. The boxes denote the median and the 25th and 75th percentiles, while the whiskers denote the 10th and 90th percentiles. Outliers are marked with a black dot, and the open squares mark that no data are available for this sample type. The numbers within parenthesis represent the number of samples for each sample type.

\subsection{Soils}

Analysis of ${ }^{14} \mathrm{C}$ in the soil profile in the southern part of the catchment (Fig. 4a) shows that the lower most sample is about 4000 years old. It is also apparent that the three samples from the upper $40 \mathrm{~cm}$ all have a modern ${ }^{14} \mathrm{C}$ signal and that the three samples from the 50 to $80 \mathrm{~cm}$ depth interval all have an age of around 2300 years (Fig. 9).

Using the 24 soil samples in which both LOI and total carbon were analysed and that had carbon concentrations above $1 \%$, the site-specific carbon:LOI ratio was calculated $(0.52 \pm 0.05)$. The highest concentrations of organic matter in soils were found in the areas with peaty silt (LOI of 2-30\%), while upland soils generally contained smaller amounts of organic matter (LOI of 0.2 to $11 \%$ ). Soil organic matter showed a narrow range of $\delta^{13} \mathrm{C}$ around $-26 \%$, i.e., 

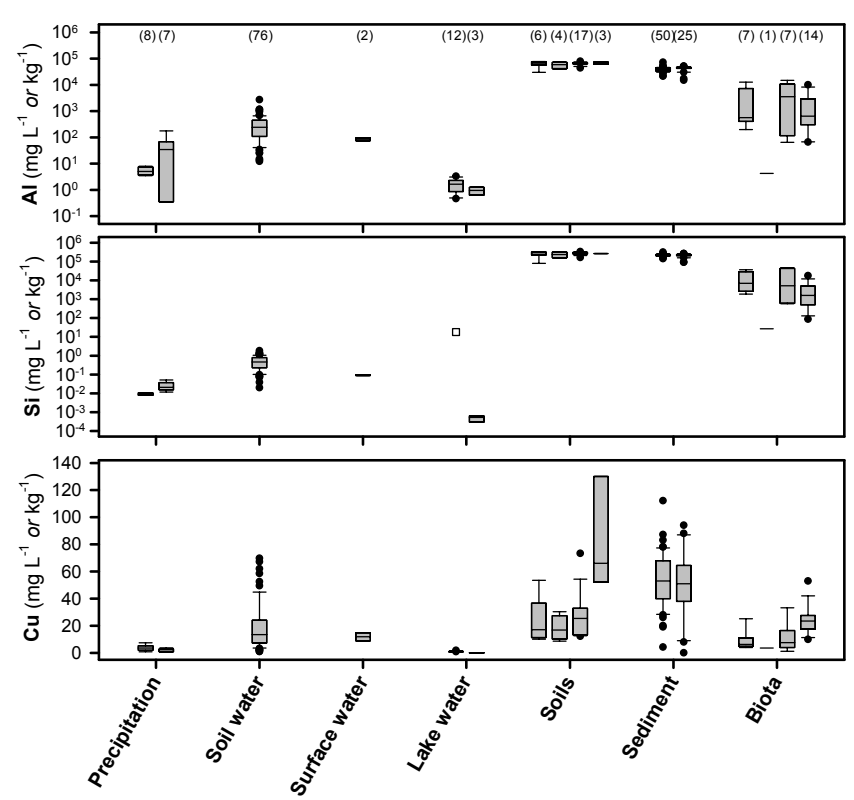

Figure 12. Box plot showing the concentrations of aluminum, silicon and copper in different sample types (the concentrations are expressed in $\mathrm{mg} \mathrm{L}^{-1}$ for water samples and in $\mathrm{mg} \mathrm{kg}^{-1}$ for solid samples). The two boxes for precipitation represent rain (left) and snow (right). The two boxes for lake water represent lake water (left) and suspended matter (right). The four boxes for soils represent (from left to right) silt, $\mathrm{O}$ horizon, peaty-silt active layer and peaty-silt permafrost. The two boxes for sediments represent samples collected from water depths $<14 \mathrm{~m}$ (left) and >14 m (right). The four boxes for biota represent (from left to right) terrestrial primary producers, terrestrial consumers, aquatic primary producers and aquatic consumers. The boxes denote the median and the 25 th and 75 th percentiles, while the whiskers denote the 10th and 90th percentiles. Outliers are marked with a black dot, and the open squares mark that all analysed samples were below the detection limit. The numbers within parenthesis represent the number of samples that were analysed for each sample type.

slightly more depleted than the soil water (Fig. 11). The total aluminium, silicon and copper concentrations were, as can be expected, much higher in soils as compared to the water samples. Total concentrations for aluminium generally ranged from 3 to $7 \%$ depending on soil type (silt, O horizon or peaty silt), silicon ranged from 8 to $33 \%$ and copper from 4 to $130 \mathrm{mg} \mathrm{kg}^{-1}$ (Fig. 12). The concentrations of aluminium, silicon and copper in the solutions from the ammonium acetate leaching were around 2, 4 and 1 orders of magnitude lower, respectively, when compared to the total concentrations.

\subsection{Lake sediments}

Even though there are considerable differences in the downcore trends for the 13 surface sediment cores, a couple of general features do exist. All cores show a more or less pro-
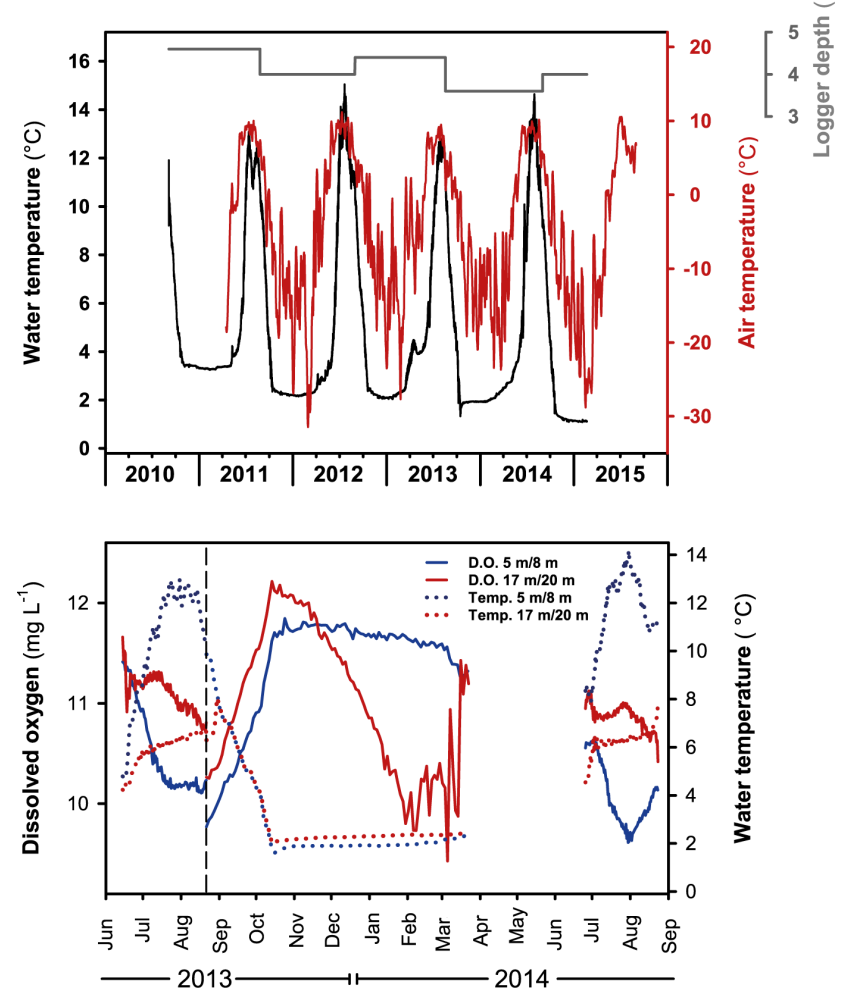

Figure 13. Upper figure: graph displaying the variations in lake water temperature at about $4 \mathrm{~m}$ water depth and air temperature during the period from 2011 to 2015 . The black line represents lake water temperature, the red line the air temperature, and the grey line represents the exact depth of the lake water temperature logger. Lower figure: graph displaying the variations in dissolved oxygen and temperature during measurements in 2013 and 2014. The dashed line represents the time when the depth of the loggers was changed from 5 and $17 \mathrm{~m}$ to 8 and $20 \mathrm{~m}$.

nounced increase in organic material (as indicated by the increasing carbon concentrations) in the topmost sediment sample. This is likely to a large extent a result of degradation of organic matter in the most recent sediment layers (Gälman et al., 2008). All cores also show a more long-term increase in organic material in the top 5 to $20 \mathrm{~cm}$ of the cores.

Depending on whether the cores were collected in areas with or without benthic vegetation, they can be grouped into two categories. First, cores from locations with benthic vegetation, i.e., cores taken at water depths of less than $14 \mathrm{~m}$, showed carbon concentrations in the top $5 \mathrm{~cm}$ ranging from 6 to $16 \%$. Aluminium, silicon and copper concentrations were $2-7,14-31 \%$ and $4-112 \mathrm{mg} \mathrm{kg}^{-1}$, respectively, while phosphorus concentrations ranged from 800 to $1300 \mathrm{mg} \mathrm{kg}^{-1}$ (Fig. 12). The bulk density of the sediment ranges from 30 to $125 \mathrm{mg} \mathrm{cm}^{-3}$. Second, at deeper locations without benthic vegetation, i.e., deeper than $14 \mathrm{~m}$, the carbon concentration in the top $5 \mathrm{~cm}$ of the core ranges from 1 to $11 \%$. Aluminium, silicon and copper concentrations were 1.5-7, 
9-26\% and 0-94 $\mathrm{mg} \mathrm{kg}^{-1}$, respectively, while phosphorus concentrations ranged from 1100 to $2600 \mathrm{mg} \mathrm{kg}^{-1}$ (Fig. 12). For the deeper locations, the bulk density was a little higher, from 60 to $700 \mathrm{mg} \mathrm{cm}^{-3}$. The $\delta^{13} \mathrm{C}$ values of all sediments showed a much larger range than the soil samples $(-31$ to $-23 \%$; Fig. 11), and there was also considerable variation in $\delta^{15} \mathrm{~N}$ values $(-0.8$ to $3.5 \%$ ).

In order to compare the sediment accumulation across the TBL basin, a number of the sediment profiles were analysed for ${ }^{210} \mathrm{~Pb}$. A number of moss macrofossils were also dated through ${ }^{14} \mathrm{C}$ analysis. The sediment depth where the sediment is about 150 years - i.e., the sediment level where atmospherically supplied, unsupported, ${ }^{210} \mathrm{~Pb}$ no longer can be detected (Appleby, 2008) - was between 5 and $12 \mathrm{~cm}$ in the six cores where ${ }^{210} \mathrm{~Pb}$ was analysed (TBL-1, 5, 6, 8, 10, 13). The calibrated ages of the ${ }^{14} \mathrm{C}$-dated macrofossils are all between 0 and 500 years, which is a period that is very difficult to date accurately due to the large variations in the atmospheric ${ }^{14} \mathrm{C}$ concentrations resulting from the increased burning of fossil fuels (Reimer et al., 2013). This results in very broad calibrated age ranges with many possible dates, which complicate the interpretation (Fig. 9). In one of the sediment cores (TBL-4), it is likely that the modern ${ }^{14} \mathrm{C}$ signature of the sample indicates that the analysed macrofossil was pushed down through the sediment by the corer, indicating that this result should not be used.

\subsection{Terrestrial biota}

Generally, lichens, bryophytes and litter (i.e., material found on or close to the ground) had more attached mineral particles compared to standing litter and standing living biomass. Assuming that pure plant material gives an ash content of approximately $5 \%$, standing living biomass had a mineral particle content of almost zero.

The most exposed habitat, ridges with dry grassland, had the lowest biomass, and it was found that biomass increased in the order meadow, wetland and Betula vegetation types. This pattern was consistent among both sampling campaigns (mid-August 2011 and late June 2014). Even if it could be expected that standing biomass would be higher later in the season, the opposite pattern was found for both the Betula and the wetland vegetation types. A closer examination suggests that, at least for the Betula vegetation type, this can be attributed to denser stands being sampled in 2011 than in 2014 (higher wood biomass). Bryophytes were also more dominant in the sampling plots used during the 2014 sampling campaign. For the dry ridges the observed higher biomass in June is consistent with expectations, i.e., that peak biomass should occur when the moisture content still is relatively high.

Both when comparing the main and the replicate plots from the 2011 sampling and when comparing the 2011 and 2014 sampling campaigns, there was a high variability in biomass for the different functional groups. This suggests that the smaller plots $\left(0.2 \times 0.2 \mathrm{~m}\right.$ and $\left.170 \mathrm{~cm}^{2}\right)$ used in this study might not be large enough to capture the spatial heterogeneity within each vegetation type. Hence, it is expected that the larger plots $(0.5 \times 0.5 \mathrm{~m})$ should provide the most reliable estimates of terrestrial biomass. Furthermore, it is worth noting that the primary objective of the $170 \mathrm{~cm}^{2}$ plots used in the 2014 sampling campaign was to relate respiration and production to biomass, litter and organic content in the soil and not to estimate total biomass. Terrestrial primary producers had $\delta^{13} \mathrm{C}$ and $\delta^{15} \mathrm{~N}$ values of $-29 \pm 1$ and $-0.4 \pm 3 \%$, respectively, while the single sample from a terrestrial consumer had $\delta^{13} \mathrm{C}$ and $\delta^{15} \mathrm{~N}$ of -24 and $4.3 \%$ (Fig. 11). In primary producers the concentrations of aluminium, silicon and copper were $0.02-1.3,0.2-3.7 \%$ and $4-25 \mathrm{mg} \mathrm{kg}^{-1}$, respectively, while our only sample of a terrestrial consumer showed considerably lower concentrations, i.e., $0.0004,0.003 \%$ and $4 \mathrm{mg} \mathrm{kg}^{-1}$ for aluminium, silicon and copper, respectively (Fig. 12).

\subsection{Aquatic biota}

The dominant phytoplankton taxon in August 2011 and April 2012 was Dinophyceae followed by Chyptophyceae. In August 2012, Chlorophyceae was the dominant phytoplankton type, followed by Cryptophyceae. Phytoplankton biomass varied between 13 and $62 \mathrm{mg} \mathrm{C} \mathrm{m}^{-3}$. Bacterioplankton biomass was considerably higher in the samples from August 2011 (on average $0.023 \mathrm{~g} \mathrm{C} \mathrm{m}^{-3}$ ) than in the samples from 2012 (average values of 0.012 and $0.010 \mathrm{~g} \mathrm{C} \mathrm{m}^{-3}$ for April and August, respectively). The zooplankton community was dominated by Copepoda and Cladocera (mainly Daphnia), and zooplankton biomass ranged between 0.01 to $0.07 \mathrm{~g} \mathrm{C} \mathrm{m}^{-3}$.

Contrary to bacterioplankton, benthic bacterial biomass was higher in samples from 2012 (average $1.4 \mathrm{~g} \mathrm{C} \mathrm{m}^{-2}$ ) than in samples from $2012\left(0.6 \mathrm{~g} \mathrm{C} \mathrm{m}^{-2}\right)$. The diversity and biomass of benthic fauna were low, and several of the Ekman grabs contained no benthic macrofauna $(0-1758$ individuals per $\mathrm{m}^{2}$ ). The benthic fauna was dominated by Chironomidae and Oligochaeta.

Fontinalis antipyretica and Chara spp. dominated the macrophytes community in the lake but several more species (ca. 20 including vascular plants, bryophytes and epiphytic algae) were identified during the macrophytes mapping of the lake. There were dense stands of macrophytes in wind-sheltered littoral and lower coverage and biomasses of macrophytes in wind-exposed littoral zones. Biomass measured in 2011 varied between less than 1 to $1382 \mathrm{~g} \mathrm{DW} \mathrm{m}^{-2}$. The dive transect in 2013 did not show correlation of biomass with depth but showed that there were high biomasses of macrophytes also at depths greater than $16 \mathrm{~m}$. Mean biomass at the different depths 1.6, 2.5, 5.2, 9.2 and $16.3 \mathrm{~m}$ was 155 , $55,100,137$ and $52 \mathrm{~g} \mathrm{DW} \mathrm{m}^{-2}$, respectively.

Primary production measured in glass bottles showed that respiration was higher than production in the pelagic 


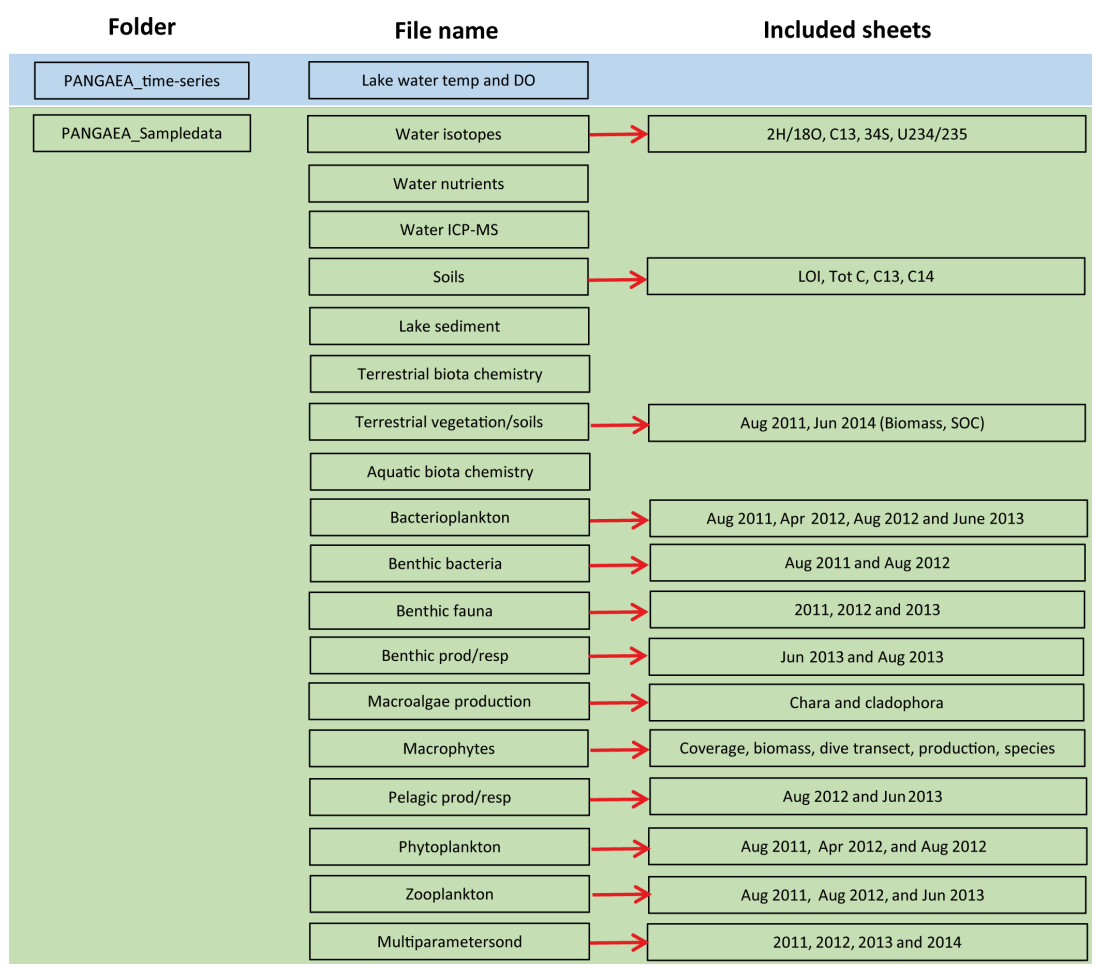

Figure 14. Illustration of folders, resulting data tables and associated sheets in the PANGAEA database.

habitat in both August 2012 and June 2013. Gross primary production in the water column was higher in $\mathrm{Au}$ gust (mean of $0.7 \mathrm{~g} \mathrm{C} \mathrm{m}^{-2} \mathrm{~h}^{-1}$ ) than in June (mean of $0.2 \mathrm{~g}$ $\mathrm{C} \mathrm{m}^{-2} \mathrm{~h}^{-1}$ ). As expected, considering the higher water temperature in late summer, the respiration was also higher in August $\left(0.25 \mathrm{~g} \mathrm{C} \mathrm{m}^{-3} \mathrm{~h}^{-1}\right)$ than in June $\left(0.006 \mathrm{~g} \mathrm{C} \mathrm{m}^{-3} \mathrm{~h}^{-1}\right)$. Benthic production and respiration measured in transparent chambers showed that primary production was higher than respiration in both June and August during daytime (increase in oxygen concentrations). When including the dark hours and measuring for $24 \mathrm{~h}$, respiration was higher than primary production in the benthic habitat in August (decrease in oxygen concentration) even though primary production during light hours was higher in August (mean net production at $0.7 \mathrm{~m}$ depth: $0.2 \mathrm{mg} \mathrm{O}_{2} \mathrm{~m}^{-2}$ ) than in June (mean net production at $0.7 \mathrm{~m}$ depth: $0.03 \mathrm{mg} \mathrm{O}_{2} \mathrm{~m}^{-2}$ ). The production measurements on pieces of macroalgae showed that Chara sp. had similar production at 2, 5 and $10 \mathrm{~m}$ depth although there was a trend towards lower primary production with depth (mean production 0.038, 0.032 and $0.025 \mathrm{~g} \mathrm{O}_{2} \mathrm{~g} \mathrm{DW}^{-1} \mathrm{~h}^{-1}$ at 2,5 and $10 \mathrm{~m}$, respectively). The production of Cladophora sp. at $5 \mathrm{~m}$ depth (mean production of 0.022 , minimum of 0.013 , maximum of $0.035 \mathrm{~g} \mathrm{O}_{2} \mathrm{~g} \mathrm{DW}^{-1} \mathrm{~h}^{-1}$ ) was somewhat lower than the production of Chara sp. at corresponding depth (mean production of 0.032 , minimum of 0.030 , maximum of $\left.0.035 \mathrm{~g} \mathrm{O}_{2} \mathrm{~g} \mathrm{DW}^{-1} \mathrm{~h}^{-1}\right)$. $\delta^{13} \mathrm{C}$ and $\delta^{15} \mathrm{~N}$ in aquatic primary producers varied considerably between species (Fig. 11). Nostoc sp. had a $\delta^{13} \mathrm{C}$ of $-9 \%$ and a $\delta^{15} \mathrm{~N}$ of $-0.4 \%$, while aquatic bryophytes and Chara sp. had $\delta^{13} \mathrm{C}$ and $\delta^{15} \mathrm{~N}$ of -28 and $1.24 \%$ and -15 and $1.3 \%$, respectively. Aquatic consumers showed a much narrower range in $\delta^{13} \mathrm{C}$ and $\delta^{15} \mathrm{~N}$, with averages of $-25 \pm 3$ and $3.8 \pm 1.8 \%$, respectively (Fig. 11). Concentrations of aluminium, silicon and copper in aquatic primary producers were $0.01-1.5,0.1-5 \%$ and $1-33 \mathrm{mg} \mathrm{kg}^{-1}$, respectively. Aquatic consumers had slightly lower concentrations for aluminium and silicon $-0.1-1$ and $0.01-2 \%$, respectively but slightly higher copper concentrations $-10-52 \mathrm{mg} \mathrm{kg}^{-1}$ (Fig. 12).

\section{Conclusions}

This paper presents a large and comprehensive biogeochemical data set covering both the terrestrial and aquatic environments in a periglacial catchment. By the inclusion of data from both liquid and solid phases, as well as abiotic and biotic components, this data set allows for the calculation of whole-ecosystem mass balance budgets for a long list of elements. Together with the hydrological data presented by Johansson et al. (2015a), it also allows for calculations of fluxes between different catchment compartments as well as the development of ecosystem models. 


\section{Data availability}

We encourage anyone interested in using the data set to contact the corresponding author regarding any questions about the data or the field site. To our knowledge, this data set is unique for periglacial environments and is freely available at PANGAEA, doi:10.1594/PANGAEA.860961. A schematic figure of the PANGAEA tables is shown in Fig. 14.

Author contributions. Tobias Lindborg prepared the manuscript with contributions from all coauthors and he has been involved in all fieldwork and data processing related to the data presented in the present paper. Tobias Lindborg was also responsible for the overall field campaign strategy.

Johan Rydberg was involved in the sediment sampling and has written the associated sections in the present paper as well as taking active part in the writing of the whole manuscript.

Mats Tröjbom was involved in the chemistry sampling programme and the data set preparation to the PANGAEA database.

Sten Berglund was involved in the field work and took active part in the writing of the whole paper.

Emma Johansson was involved in the field work and has produced maps and other figures to the present paper. She also prepared the data set for storage in the PANGAEA database.

Johannes Petrone prepared the data set for storage in the PANGAEA database and was involved in parts of the field work described in this paper. Ander Löfgren, Peter Saetre, Eva Andersson and Sara Nordén were involved in the terrestrial and aquatic sampling programmes as well as writing associated texts.

Micke Borgiel was responsible for the macrophyte dive transect inventory. Gustav Sohlenius was involved in the soil sampling.

Ulrik Kautsky and Hjalmar Laudon were involved in field work and different measurement campaigns described in the present paper. They also contributed to the overall field campaign strategy.

Tobias Lindborg (ecology and chemistry) and Emma Johansson (hydrology and meteorology) are responsible for the GRASP field programme.

Acknowledgements. The work was conducted as a part of the Greenland Analogue Surface Project (GRASP) funded by the Swedish Nuclear Fuel and Waste Management Company (SKB). The authors would like to thank the Greenland Analogue Project (GAP) and Kangerlussuaq International Science Support (KISS) for providing logistical support throughout the years.

Edited by: A. Demény

Reviewed by: J. White and J. Stern

\section{References}

Anderson, N. J., Harriman, R., Ryves, D. B., and Patrick, S. T.: Dominant factors controlling variability in the ionic composition of West Greenland lakes, Arct. Antarct. Alp. Res., 33, 418-425, 2001.
Anderson, N. J., Brodersen, K. P., Ryves, D. B., McGowan, S., Johansson, L. S., Jeppesen, E., and Leng, M. J.: Climate versus in-lake processes as controls on the development of community structure in a low-Arctic lake (South-West Greenland), Ecosystems, 11, 307-324, doi:10.1007/s10021-007-9123-y, 2008.

Anderson, N. J., D'Andrea, W., and Fritz, S. C.: Holocene carbon burial by lakes in SW Greenland, Glob. Change Biol., 15, 25902598, doi:10.1111/j.1365-2486.2009.01942.x, 2009.

Appleby, P. G.: Three decades of dating recent sediments by fallout radionuclides: a review, Holocene, 18, 83-93, doi:10.1177/0959683607085598, 2008.

Bronk Ramsey, C.: Bayesian analysis of radiocarbon dates, Radiocarbon, 51, 337-360, 2009.

Cappelen, J. (Ed.): Weather observations from Greenland 19582015 - Observation data with description, Danish Meteorological Institute, Copenhagen, Denmark, DMI Report 16-08, 2016.

Chapin F. S., Shaver G. R., Giblin A. E., Nadelhoffer K. J., and Laundre J. A.: Responses of arctic tundra to experimental and observed changes in climate, Ecology, 76, 694-711, 1995.

Clarhäll, A.: SKB studies of the periglacial environment - report from field studies in Kangerlussuaq, Greenland 2008 and 2010, SKB P-11-05, Svensk Kärnbränslehantering AB, Stockholm, Sweden, 2011.

Engels, S. and Helmens, K.: Holocene environmental changes and climate development in Greenland, Svensk Kärnbränslehantering AB, SKB R-10-65, Stockholm, Sweden, 2010.

Gälman, V., Rydberg, J., Sjöstedt de-Luna, S., Bindler, R., and Renberg, I.: Carbon and nitrogen loss rates during ageing of lake sediment: Changes over 27 years studied in a varved lake sediment, Limnol. Oceanogr., 53, 1076-1082, 2008.

Harper, J., Hubbard, A., Ruskeeniemi, T., Claesson Liljedahl, L., Lehtinen, A., Booth, A., Brinkerhoff, D., Drake, H., Dow, C., Doyle, S., Engström, J., Fitzpatrik, A., Frape, S., Henkemans, E., Humphrey, N., Johnson, J., Jones, G., Joughin, I., Klint, K. E., Kukkonen, I., Kulessa, B., Londowski, C., Lindbäck, K., Makahnouk, M., Meierbachtol, T., Pere, T., Pedersen, K., Petterson, R., Pimentel, S., Quincey, D., Tullborg, E. L., and van As, D.: The Greenland Analogue Project Yearly Report 2010, Svensk Kärnbränslehantering AB, Stockholm, Sweden, Report SKB R-11-23, 2011.

Helcom: Manual for Marine Monitoring in the Combine Programme of Helcom, available at: http://helcom.fi/Documents/Action areas/Monitoring and assessment/Manuals and Guidelines/Manual for Marine Monitoring in the COMBINE Programme of HELCOM.pdf, last access: 4 April 2016.

Hindshaw, R. S., Lang, S. Q., Bernasconi, S. M., Heaton, T. H. E., Lindsay, M. R., and Boyd, E. S.: Origin and temporal variability of unusually low $\delta^{13} \mathrm{C}$-DOC values in two high Arctic catchments, J. Geophys. Res.-Biogeo., 121, 1073-1085, doi:10.1002/2015JG003303, 2016.

Hua, Q., Barbetti, M., and Rakowski, A. Z,: Atmospheric radiocarbon for the period 1950-2010, Radiocarbon, 55, 2059-2072, 2013.

Jessen, S., Holmslykke, H. D., Rasmussen, K., Richardt, N., and Holm, P. E.: Hydrology and pore water chemistry in a permafrost wetland, Ilulissat, Greenland, Water Resour. Res., 50, 47604774, doi:10.1002/2013WR014376, 2014. 
Johansson, E., Berglund, S., Lindborg, T., Petrone, J., van As, D., Gustafsson, L.-G., Näslund, J.-O., and Laudon, H.: Hydrological and meteorological investigations in a periglacial lake catchment near Kangerlussuaq, west Greenland - presentation of a new multi-parameter data set, Earth Syst. Sci. Data, 7, 93-108, doi:10.5194/essd-7-93-2015, 2015a.

Johansson, E., Gustafsson, L.-G., Berglund, S., Lindborg, T., Selroos, J.-O., Claesson Liljedahl, L., and Destouni, G.: Data evaluation and numerical modeling of hydrological interactions between active layer, lake and talik in a permafrost catchment, Western Greenland, J. Hydrology, 527, 688-703, doi:10.1016/j.jhydrol.2015.05.026, 2015b.

Johansson, J.-Å., Olofsson, H., and Ramberg, L.: Studier av zooplanktons konsumtion i Botjärn, Limnologiska inst., Uppsala universitet, Sweden, Klotenprojektets rapport nr. 5, 27 pp., 1976.

Kautsky, U.: Ecosystem processes in coastal areas of the Baltic Sea, $\mathrm{PhD}$ thesis, Department of Zoology, Stockholm University, Sweden, 1995.

Loferer-Krössbacher, M., Klima, J., and Psenner, R.: Determination of bacterial cell dry mass by transmission electron microscopy and densitometric image analysis, Appl. Environ. Microbiol., 64, 688-694, 1998.

Lundin, E. J., Klaminder, J., Giesler, R., Persson, A., Olefeldt, D., Heliasz, M., Christensen, T. R., and Karlsson, J.: Is the subarctic landscape still a carbon sink? Evidence from a detailed catchment balance, Geophys. Res. Lett., 43, 1988-1995, doi:10.1002/2015GL066970, 2016.

McGuire, A. D., Anderson, L. G., Christensen, T. R., Dallimore, S., Guo, L., Hayes, D. J., Heimann, M., Lorenson, T.D., Macdonald, R. W., and Roulet, N.: Sensitivity of the carbon cycle in the Arctic to climate change, Ecol. Monogr., 79, 523-555, doi:10.1890/08-2025.1, 2009.

Moy, F. E., Dahl, K., Karlsson, J., Kautsky, H., Ruuskanen, A., and Carstensen, J.: Nordic intercalibration of hard bottom macroalgae monitoring methodologies, Algamony, Nordic Council of Ministers, Copenhagen, Denmark, TemaNord 2010:543, 2010.

Olrik, K., Blomqvist, P., Brettum, P., Cronberg, G., and Eloranta, P.: Methods for quantitative assessment of phytoplankton in freshwaters, Part 1: Sampling, processing, and application in freshwater environmental monitoring programmes, Naturvårdsverket, Stockholm, Sweden, Rapport 4860, 1998.

Palmtag, J., Hugelius, G., Lashchinskiy, N., Tamstorf, M. P., Richter, A., Elberling, B., and Khury, P.: Storage, landscape distribution, and burial history of soil organic matter in contrasting areas of continuous permafrost, Arct. Antarct. Alp. Res., 47, 7188, doi:10.1657/aaar0014-027, 2015.

Petrone, J., Sohlenius, G., Johansson, E., Lindborg, T., Näslund, J.O., Strömgren, M., and Brydsten, L.: Using ground-penetrating radar, topography and classification of vegetation to model the sediment and active layer thickness in a periglacial lake catchment, Western Greenland, Earth Syst. Sci. Data Discuss., doi:10.5194/essd-2016-19, in review, 2016.

Petrone, K., Buffam, I., and Laudon, H.: Hydrologic and biotic control of nitrogen export during snowmelt: a combined conservative and reactive tracer approach, Water Resour. Res., 43, W06420, doi:10.1029/2006WR005286, 2007.

Reimer, P. J., Bard, E., Bayliss, A., Beck, J. W., Blackwell, P. G., Bronk Ramsey, C., Buck, C. E., Cheng, H., Edwards, R. L., Friedrich, M., Grootes, P.-M., Guilderson, T. P., Haflidason, H.,
Hajdas, I., Hatté, C., Heaton, T. J., Hoffmann, D. L., Hogg, A. G., Hughen, K. A., Kaiser, K. F., Kromer, B., Manning, S. W., Niu, M., Reimer, R. W., Richards, D. A., Scott, E. M., Southon, J. R., Staff, R. A., Turney, C. S. M., and van der Plicht, J.: IntCal13 and Marine13 radiocarbon age calibration curves $0-50000$ years cal BP, Radiocarbon, 55, 1869-1887, 2013.

Renberg, I. and Hansson, H.: The HTH sediment corer, J. Paleolimnol., 40, 655-659, doi:10.1007/s 10933-007-9188-9, 2008.

Ruttner-Kolisko, A.: Suggestions for biomass calculations of plankton rotifers, Arch. Hydrobiol. Beih. Ergebn. Limnol., 8, 71-76, 1977.

Rydberg, J.: Wavelength dispersive X-ray fluorescence spectroscopy as a fast, non-destructive and cost-effective analytical method for determining the geochemical composition of small loose-powder sediment samples, J. Paleolimnol., 52, 265-276, doi:10.1007/s10933-014-9792-4, 2014.

Rydberg, J., Klaminder, J., Rosén, P., and Bindler, R.: Climate driven release of carbon and mercury from permafrost mires increases mercury loading to sub-arctic lakes, Sci. Total Environ., 408, 4778-4783, doi:10.1016/j.scitotenv.2010.06.056, 2010.

Rydberg, J., Lindborg, T., Solenius, G., Reuss, N., Olsen, J., and Laudon, H.: The importance of eolian input on lakesediment geochemical composition in the dry proglacial landscape of western Greenland, Arct. Antarct. Alp. Res., 48, 93109, doi:10.1657/AAAR0015-009, 2016.

Rysgaard, S. and Glud, R. N. (Eds.): Carbon cycling in Arctic marine ecosystems: Case study Young Sound, the Commission for Scientific Research in Greenland, Meddelelser om Grønland, Bioscience 58, Copenhagen, Denmark, 2007.

Ryves, D. B., McGowan, S., and Anderson, N. J.: Development and evaluation of a diatom-conductivity model from lakes in West Greenland, Freshwater Biol., 47, 995-1014, doi:10.1046/j.13652427.2002.00832.x, 2002.

Ryves, D. B., Battarbee, R. W., and Fritz, S. C.: The dilemma of disappearing diatoms: incorporating diatom dissolution data into palaeoenvironmental modelling, Quaternary Sci. Rev., 28, 120 136, doi:10.1016/j.quascirev.2008.08.021, 2009.

Saros, J. E., Strock, K. E., McCue, J., Hogan, E., and Anderson, N. J.: Response of Cyclotella species to nutrients and incubation depth in Arctic lakes, J. Plankton Res. 36, 450-460, doi:10.1093/plankt/fbt126, 2014.

Schuur, E. A. G., McGuire, A. D., Schädel, C., Grosse, G., Harden, J. W., Hayes, D. J., Hugelius, G., Koven, C. D., Kuhry, P., Lawrence D. M., Natali S. M., Olefeldt, D., Romanovsky V. E., Schaefer, K., Turetsky, M. R., Treat, C. C., and Vonk, J. E.: Climate change and the permafrost carbon feedback, Nature, 520, 171-179, doi:10.1038/nature14338, 2015.

Smol, J. P.: Climate change: A planet in flux, Nature, 483, S12-S15, doi:10.1038/483S12a, 2012.

Smol, J. P. and Douglas, M. S. V.: From controversy to consensus: making the case for recent climate change in the Arctic using lake sediments, Front. Ecol. Environ., 5, 466-474, 2007.

Sobek, S., Anderson, N. J., Bernasconi, S. M., and Del Sontro, T.: Low organic carbon burial efficiency in Arctic lake sediments, J. Geophys. Res. Biogeo., 119, 1231-1243, doi:10.1002/2014JG002612, 2014.

Solomon, C. T., Jones, S. E., Weidel, B. C., Buffam, I., Fork, M. L., Karlsson, J., Larsen, S., Lennon, J. T., Read, J. S., Sadro, S., and Saros, J. E.: Ecosystem consequences of chang- 
ing inputs of terrestrial dissolved organic matter to lakes: Current knowledge and future challenges, Ecosystems, 18, 376-389, doi:10.1007/s10021-015-9848-y, 2015.

Tarnocai, C., Canadell, J. G., Schuur, E. A. G., Kuhry, P., Mazhitova, G., and Zimov, S.: Soil organic carbon pools in the northern circumpolar permafrost region, Global Biogeochem. Cy., 23, GB2023, doi:10.1029/2008GB003327, 2009.

van Tatenhove, F. G. M. and Olesen, O. B.: Ground temperature and related permafrost characteristics in West Greenland, Permafrost Periglac., 5, 199-215, 1994.
Whiteford, E. J., McGowan, S., Barry, C. D., and Anderson, N. J.: Seasonal and regional controls of phytoplankton production along a climate gradient in South-West Greenland during icecover and ice-free conditions, Arct. Antarct. Alp. Res., 48, 139159, doi:10.1657/AAAR0015-003, 2016. 